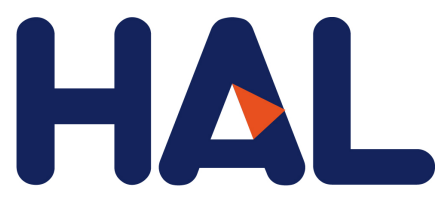

archives-ouvertes

\title{
Evaluating the impact of a working time regulation on capital operating time. The French 35 -hour work week experience
}

Fabrice Gilles

\section{- To cite this version:}

Fabrice Gilles. Evaluating the impact of a working time regulation on capital operating time. The French 35-hour work week experience. 2014. hal-01006765

\section{HAL Id: hal-01006765 \\ https://hal.univ-lille3.fr/hal-01006765}

Submitted on 16 Jun 2014

HAL is a multi-disciplinary open access archive for the deposit and dissemination of scientific research documents, whether they are published or not. The documents may come from teaching and research institutions in France or abroad, or from public or private research centers.
L'archive ouverte pluridisciplinaire HAL, est destinée au dépôt et à la diffusion de documents scientifiques de niveau recherche, publiés ou non, émanant des établissements d'enseignement et de recherche français ou étrangers, des laboratoires publics ou privés. 


\section{Document de travail}

"Evaluating the impact of a working time regulation on capital operating time. The French 35-hour work week experience"

Fabrice Gilles

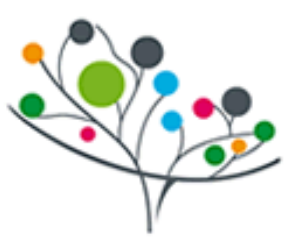

Université Lille Nord de France 


\section{"Evaluating the impact of a working time regulation on capital operating time. \\ The French 35-hour work week experience"}

\section{Fabrice Gilles}

PRES Université Lille Nord de France, Université Lille 1, Laboratoire EQUIPPE, EA 4018, Villeneuve d'Ascq, France

fabrice.gilles@univ-lille1.fr 


\title{
Evaluating the impact of a working time regulation on capital operating time.
}

\section{The French 35-hour work week experience ${ }^{1}$}

\author{
Fabrice Gilles ${ }^{2}$
}

\begin{abstract}
According to the literature on work-sharing, productivity gains on capital equipment may increase employment while diminishing weekly working hours. In this article, we evaluate the impact of the French 35-hour working week on capital operating time. We merge the French survey on Capital Operating Time (COT, Banque de France, Central Bank of France; 1989-2004) and administrative Working Time Reduction agreements files (WTR, DARES, French Ministry of Labour; May 2003). We construct shift-work-based capital operating time indicators. Using differences-in-differences econometric models, we show that the implementation of the 35-hour work week did not induce any reduction in COT. Hence, firms increase shift-work to compensate for the decrease in working hours.
\end{abstract}

Keywords: working time regulation, capital operating time, causal effect, differences-in-differences models.

JEL Classification: C14, D23, J31, J38.

\section{Introduction}

In this paper, we evaluate the impact of the French 35-hour working week on (teamwork or) shift-work and capital operating time (COT), i.e. the average time that capital equipment are in use in firms. In response to the high levels of unemployment in the late 1990s, in 1998 and 2000 respectively, the French government decided to adopt the Aubry 1 and 2 laws (hereafter the Aubry reform) to reduce the

\footnotetext{
1 The author is grateful to Banque de France and more particularly to Mireille Bardos for offering an internship (JulySeptember 2005) at the "Observatoire des Entreprises" service; to Didier Cochonneau for help manipulating the data, and to Gilbert Cette for advice; thanks also to Pierre Cahuc, Yannick L'Horty, Ferhat Mihoubi, Pierre Morin, and Sébastien Roux. This study benefited from comments made by participants at the $24^{\text {èmes }}$ Journées de Microéconomie Appliquée (Fribourg, 2007), the 56 ${ }^{\text {ème }}$ Congrès de l'Association Française de Science Economique (Paris, 2007), the 20 ${ }^{\text {th }}$ EALE meeting (Amsterdam, 2008), where preliminary drafts were presented. All opinions and errors are my own.

${ }^{2}$ Universités de Lille and EQUIPPE. E-mail: fabrice.gilles@ univ-lille1.fr. Address: Université de Lille 1, Faculté des Sciences Economiques et Sociales, Cité Scientifique, 59655 Villeneuve d'Ascq Cedex, FRANCE.
} 
standard weekly working time, i.e. the number of working hours that serves as the threshold beyond which workers benefit from an overtime premium, from 39 hours down to 35 hours. This refers to a work sharing policy: reduced hours worked by employees to be replaced by newly created jobs. Since then, many theoretical (d'Autume and Cahuc, 1997; Cahuc, 2001; Marimon and Zilibotti, 2000; Ortega, 2003; Osuna and Rios-Rull, 2003, or Rocheteau, 2002) and empirical (Bunel and Jugnot, 2003; Crépon et al., 2004; Estevão and Sá, 2008; Fiole et al., 2000; and Logeay and Schreiber, 2006) economic analyses have evaluated the impact of this policy on employment.

Some studies try to measure the effect of this working time regulation or reduction (WTR) on the adoption by firms of innovative work practices (Askenazy, 2001 or 2003; Bunel, 2001), working conditions (Afsa and Biscourp, 2005; Askenazy, 2000) and labour or total factor productivity (Crépon et al., 2004). So far, there have been no analyses of the capital productivity gains achieved from implementation of the 35-hour working week in France. This paper studies the consequence of reducing working time on the operating time of the capital stock and shift-work in the manufacturing sector. Working time and capital operating time will differ if there is shift-work. We can see three main reasons why endogenous responses of shift-work to a reduction of working time may be important.

First, the Aubry reform allows firms to change the organisation of the work for their employees while reducing hours of work. In particular, this reorganisation could take the form of more intensive shiftwork. Moreover, the Aubry reform aimed at reducing standard hours of work from 39 to 35 hours a week, e.g. from an 8-hour to a 7-hour working day. Thus, it could have represented a major change for firms. Hence, we can expect variations in shift-work to be an important response to this attempt at work sharing.

Second, there is the widespread use of shift-work today in France. Indeed, let us consider shift-work in the sense of equally size crews replacing each other at regular intervals. By the mid-1990s, about $45 \%$ of the French manufacturing labour force performed shift-work in this sense (Sylvain, 2001). Thus, the Aubry reform could have been an opportunity for firms that already made use of such organization 
systems to increase the shift-work intensity. As well, it could have made it profitable for a number of firms that formerly employed only day workers to implement any kind of shift-work organizations, and thus to separate the operating time of their capital stock from their employees' working time.

Third, combining a cut in working time with increased shift-work is often seen as a way of preserving output and increasing employment (Anxo et al., 1995; Calmfors and Hoel, 1989). It thus appears crucial to analyse how operating time and shift-work respond endogenously to a reduction of working time, what it implies for total employment. There are many theoretical economic works analysing the effect on employment of a WTR (among others: d'Autume and Cahuc, 1997; Cahuc, 2001; Gilles and L'Horty, 2003; Hart, 1987; Langot and Pucci, 1997). Some of these models show that increased shift-work allows firms under some conditions to create more jobs than if there were no such reorganisation: allowing for shift-work can be seen as a way of preserving output (and potentially increasing employment) because it could cause capital productivity to increase and reduce the increase in production costs due to the implementation of the WTR (wage increase, decrease in labour productivity). There is also a strand of theoretical studies analysing to what extent the implementation of a WTR affects shift-work and COT (Calmfors and Hoel, 1989; de Regt, 2002). Those works define COT as the product of the number of (worker) crews - used by the firm, and the average number of weekly hours when shift-workers operate on physical capital equipment. The main results are that a WTR entails an increase in shift-work, which may compensate for the decrease in COT due to the reduced hours of work. Thus we also examine if COT has decreased, and by how much.

To answer these questions we need to evaluate to what extent the French 35-hour working week impacts COT. We merge two datasets, the administrative files related to the WTR agreements (Direction de l'Animation, de la Recherche et des Etudes Statistiques, DARES; French Ministry of Labour; May 2003) and the COT survey (Banque de France, Central Bank of France; 1989-2004). We build COT indicators directly related to shift-work. To get the causal effect of WTR on COT, we have to cope with selection 
bias because implementing a working time regulation through the Aubry reform is endogenous. To proceed, we apply conditional differences-in-differences estimators (Abadie, 2005; Blundell and Costa Dias, 2009) to an unbalanced panel (rotating panel resulting from repeated cross sections) of firms, thus controlling for differences in companies' observed and unobserved organisational features. For firms employing more than 20 workers, the French 35-hour work week has not caused any decrease in COT. In other words, firms have increased shift-work to compensate for the decreased hours of work.

Thus, this article is a complement to theoretical models that deal with work-sharing and its consequences on reorganization of the work within the firm. This question is of interest because reorganizing while reducing hours of work is linked to capital productivity gains, and to potential employment creation as mentioned in some theoretical models. This paper is an empirical evaluation that is original. Indeed, this study is rendered possible because the Aubry law is an almost unique example of a sudden exogenous shock on standard hours of work that allows studying the effect on a variety of outcomes and on COT in particular. Moreover, the data in use are original insofar they are specifically designed (administrative files of WTR agreements; COT survey) to address the COT issue within the context of a working time regulation.

The remainder of our paper is organised as follows. Section 2 displays the policy and COT measurements in line with theoretical models. Section 3 presents data and descriptive statistics. Section 4 describes the identification strategy. Section 5 presents the results. Section 6 concludes.

\section{The policy, theory and COT measurements}

In this section we describe the French policy to reduce the standard working week down to 35 hours and review the results of theoretical works on the relation between WTR, shift-work, COT and employment. We also present COT indicators considered in this paper. 


\section{The policy}

We first present the French 35 hour work week that aimed to promote job creation by introducing work sharing, within the context of the adoption of several laws that deal with regulations of hours of work.

Second, we focus more specifically on firm reorganisation through the Aubry reform (1998-2000).

\section{REDUCING WORKING TIME DOWN TO 35 HOURS A WEEK}

Box 1. Main laws concerning hours' regulations in France 1982-2004.

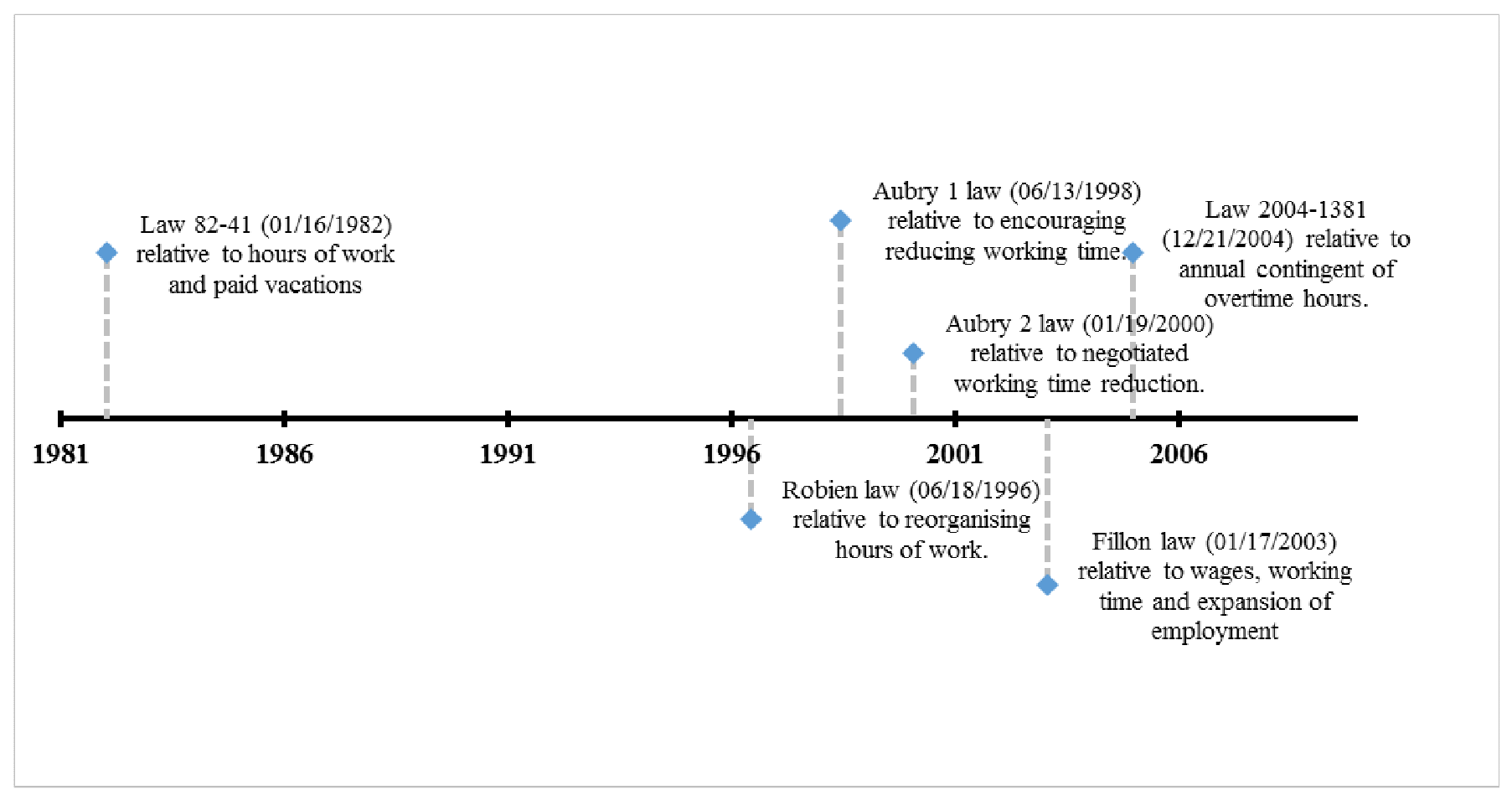

Source: Legifrance.

The time-line in Box 1 sums up regulations that are related to hours of work over 1982-2004 and is provided by Legifrance (official website of the French government for the publication of legislation, regulations, and legal information).

\section{Early laws}

At the beginning of the 1980s, the socialist government aimed to expand employment, replacing hours worked by employees with newly created jobs (so-called work sharing policy). In 1981, the goal was to

\footnotetext{
${ }^{3}$ This subsection only contains a brief description of the Aubry reform. For more details, see the comprehensive history of recent reforms dealing with regulations of working hours in France provided in Askenazy (2008).
} 
reduce step by step the standard weekly working time, i.e. the number of working hours that serves as the threshold beyond which workers benefit from an overtime premium, from 40 hours down to 35 hours by 1985. On 16 January 1982, a law was passed that reduced the standard work week from 40 hours down to 39 hours $^{4}$. Overtimes were paid at least with a $25 \%$ bonus for the first 8 hours over 39 and then a $50 \%$ premium from then onward. Because of a bad economic situation over 1982-1983, reducing more working time and the goal of 35 hours were abandoned. However, by the 1990s, the idea of a WTR returned in order to address persistent mass unemployment.

On 13 June 1996, the conservative government passed the Robien law: it aimed to encourage firms to create job, by providing large payroll tax cuts for 10 or $15 \%$ voluntary reduction in working time associated with job creations in the same proportion. Nevertheless, the Robien law was not aimed at decreasing the standard hours of work and the process met some limited success (Fiole et al., 2000).

\section{The Aubry reform}

In the autumn of 1997 , the socialist party is back to the power. The priority was then to reduce unemployment that reached a record level of $12.5 \%$ at that time. The Aubry 1 and Aubry 2 laws were adopted in France on 13 June 1998 and 19 January 2000 respectively. Their aim was to promote job creation and reduce unemployment by introducing the 35 hour work week.

The Aubry 1 law encouraged firms to reduce working time. This law was an incentive for firms to implement a WTR: it reduced the payroll taxes of employers, who reduced the working hours of their employees and committed on some job creation before 1 January 2000. In particular, firms obtained a subsidy for each worker in the firm if they raised employment by at least $6 \%$ following a decrease in working time and an even larger subsidy for an employment increase over 9\%. The Aubry 2 law officially reduced the standard working week from 39 to 35 hours - starting on 1 January 2000 for companies employing more than 20 people, and on 1 January 2002 for all other firms. Firms that decided to cut

\footnotetext{
${ }^{4}$ On that occasion, a fifth week of paid vacation was also granted.
} 
working hours of their employees once the standard working hours are reduced down to 35 hours benefited from smaller payroll tax cuts. Through Aubry 1 and 2 laws, firms were obliged to sign agreements with the unions to bargain about the size of the reduction in the effective hours of work, the increase in hourly wage rates (level of wage compensation) and the number of new jobs that would be created $^{5}$. Government could accept or not the conditions under which the WTR would be implemented. The Aubry laws did not oblige firms to adopt a 35-hour working week; firms can choose to reduce effective working time or pay overtime ${ }^{6}$. Every hours in excess of 35 hours were paid at overtime rates: firms were required to pay a compulsory overtime premium of $25 \%$ for the first 8 hours over 35 and then a $50 \%$ premium from then onward. Finally, the statutory maximum number of overtime hours a year was decreased to 130 .

\section{Further laws: Fillon adjustments}

From May 2002, the new conservative government blamed the Aubry laws for France's economic slowdown since 2001. The Fillon laws were passed by this government on 17 January 2003 and 21 December 2004. They adjust Aubry laws. They maintained the legal limit of 35 hours, but, among other things, were intended to reduce the payroll tax cuts for WTR firms and to increase them for other firms, with effect from July 2003 to July 2005. Thus, payroll tax cuts were the same for all firms and thus no longer linked to a reduction in working time. Moreover, the statutory number of overtime hours a year was increased to 220 .

\section{REORGANISING HOURS OF WORK THROUGH THE AUBRY REFORM}

The 1982 law provided limited possibilities to implement any of flexible work schedules to ease the adoption of the 39 hour work week. On the contrary, the Robien law allows reorganizing the work within the firm, but it was not aimed at decreasing more the standard weekly hours of work.

\footnotetext{
${ }^{5}$ Once this is done, workers of the given firm have to follow up, if they are concerned by the agreement.

${ }^{6}$ Firms could also decide to reduce the working week of employees by more or less than 4 hours.
} 
To compensate for a potentially large increase in production costs (reduced product per head, large wage compensation), the Aubry 1 and 2 laws allow companies to reorganise hours of their workers. This is known as the RWTR device (Reorganisation and Working Time Reduction, the so-called Aménagement et Réduction du Temps de Travail). In particular, plants were allowed to compute the annual working hours of their employees. Under the "modulation-annualisation" of hours of work, standard annual working time was also reduced from 1,820 to 1,600 hours on 1 January 2000 for firms employing more than 20 employees ${ }^{7}$. Several ways of implementing an "average 35-hour work week" throughout the year were proposed. The main modes of enforcement of a WTR by firms were as follows: a daily decrease in the number of hours of work; a weekly reduction in the number of days worked per week, month or year; annualisation of the hours of work and the introduction of night shifts (Doisneau and Daniel, 1998). Fournier et al. (2001) show that more days off (over the year) and annualisation of the hours of work were the most popular means used by firms to implement the 35-hour working week (respectively, approximately $49 \%$ and $42 \%$ of manufacturing establishments with WTR agreements up to the end of 2000).

In this paper, we focus on modulation of the hours of work. More intensive shift-work allows firms to increase COT, i.e. the average time that equipment is in use. Our question then is: has the 35-hour working week caused large increases in shift-work and in COT? This is of central importance because modifying labour organisation in the firms can change working conditions. According to Afsa and Biscourp (2004), on average, work rhythms have become more irregular as a result of the 35-hour working week, whereas Askenazy (2000) shows that RWTR should have led to changed but not less favourable working conditions. The extent to which firms changed COT following the implementation of the 35-hour work week is also investigated in several theoretical works on the impact of a WTR on employment.

\footnotetext{
${ }^{7}$ For managers, this amounts to a duration of 217 days a year. Transition periods were considered for small firms (fewer than 20 employees).
} 


\section{Theoretical results}

There are two kinds of theoretical models that focus on COT when evaluating the effects of a WTR on employment. The first type evaluate the potential impact of a WTR on job creation and often regard COT as a black box. They show that an increase or a small decrease in COT may favour job creation (d'Autume and Cahuc, 1997; Cahuc, 2001; Gilles and L'Horty, 2003). For instance, in a production factor demand model, assuming that the hours of work are given, and considering a profit maximising firm with imperfect competition, Gilles and L'Horty (2003) show that a smaller decrease in COT (than that due just to the WTR) allows the firm to economise on capital. This induces labour for capital substitution: labour demand falls and capital demand grows (substitution effect). However, since the increase in capital marginal productivity diminishes total production costs, labour demand grows (scale effect). Overall, simulating their model and taking account also of payroll tax cuts, the authors show that scale effects always dominate substitution effects. In partial equilibrium models, d'Autume and Cahuc (1997) and Cahuc (2001) get the same results, but show that RWTR can lead to job losses. Other general equilibrium studies such that of Langot and Pucci (1997) confirm the important role of COT in employment variation while reducing working time, but with a different role for reorganisation. Indeed, they show that a WTR combined with work reorganisation will lead to a smaller increase in employment levels than a WTR without any reorganisation, even if there is no WTR wage compensation. This finding is mainly due to the wage shift premium that has to be paid by firms.

The second set of studies investigates to what extent shift-work and COT increase following implementation of a WTR (Calmfors and Hoel, 1989; de Regt, 2002). Those works define COT as the product of the number of (worker) teams - used by the firm, and the average number of weekly hours when shift-workers operate on physical capital equipment. In an early paper, Calmfors and Hoel (1989) 
take account of the fact that often a wage shift premium has to be paid to workers when increasing the number of shifts, to compensate for less convenient working hours (e.g. nightshifts). ${ }^{8}$ They consider a cost minimising firm and find that a WTR leads to a decrease in the marginal cost of one shift that is greater than that in the marginal cost of a newly employed worker. Consequently, there is an increase in shift-work demand that is greater that the decrease in the hours of work; hence, COT increases. In the case of a profit maximising firm, output is no longer constant, and falls because the marginal product of employment decreases more than the factor cost of employment. Negative scale effects then can lead to an increase or a decrease in the number of shifts that is more or less proportional to the decrease in hours of work. Thus, COT can increase, decrease or remain constant. Including hourly wage increases to compensate for the WTR does not change things very much. In a more recent work, de Regt (2002) gets more optimistic results. Unlike Calmfors and Hoel (1989), the author considers that the capital stock is variable, that workers and hours are imperfect substitutes among labour services, ${ }^{9}$ and that competition in the good market is imperfect. He takes account also of the fact that the productivity of one shift may be positively or negatively related to the number of shifts. ${ }^{10} \mathrm{He}$ assumes that a large increase in shift-work can generate variable costs which need to be related to maintaining satisfactory working conditions, i.e. to pay for canteen services, heating, lightening, electricity and security, required to keep the machines in operation over a longer period of time (Hart, 1987). De Regt shows that a WTR still induces an increase in the number of shifts, but less than the size of the WTR; hence the COT decrease is smaller than the WTR. Also, the negative scale effects are smaller when the market power on the market for goods is greater, i.e. if the price elasticity of demand is low in absolute value. These models show that COT can rise, remain constant, or fall, but rarely by more than the size of the WTR. Thus, capital productivity can increase. Therefore, we want to examine: by how far has the COT fallen - or not - with the implementation of the WTR?

\footnotetext{
${ }^{8}$ This assumption is confirmed by empirical works. See Anxo et al., 1995 or Lanfranchi et al., 2002 for France; Kostiuk, 1990 , and McNabb, 1989, for the US and the UK.

${ }^{9}$ In particular, when a WTR is implemented, since hours of work fall, productivity per hour is expected to increase if the decrease in fatigue effects is larger than the increase in production slack periods.

${ }^{10}$ On the one hand, increasing the number of shift-work may allow companies to undertake operations that cannot be accomplished using a unique shift. On the other hand, increasing the number of shifts implies inconvenient working hours (night and weekend working), which may make the work harder, and mean people are less productive.
} 


\section{Indicators for COT}

To answer all these questions, we build indicators for COT that are in line with the economic literature discussed above. The operating time $U_{i}$ of particular capital equipment $i$ refers to the length of time for which it functions within a given timeframe, for example, a calendar week. According to Bosworth and Cette (1995), a 'direct measurement' of aggregate COT at the firm level is:

$$
C O T \equiv \sum_{i=1}^{M} U_{i} k_{n_{i}} \text { with } k_{n_{i}} \equiv \frac{K_{n_{i}}}{K} \text { and } \sum_{i=1}^{M} K_{n_{i}}=K
$$

where $n_{i}$ is the number of shifts that operate a given equipment $i, K_{n_{i}}$ is a sub-set of the whole capital stock $K$. This indicator is the simple arithmetic mean of the $U_{i}$ s. Through (1), we assume that companies have perfect knowledge of both the $U_{i} \mathrm{~s}$ and the $k_{n_{i}} \mathrm{~s}$. This assumption may be more reasonable when applied to small plants that make use of a smaller number of equipment types (Bosworth and Cette, 1995).

For this reason, COT usually is evaluated using indirect measures that depend either on shift-work level or energy consumption. In relation to WTR, shift-work and COT (Calmfors and Hoel, 1989; de Regt, 2002), we focus only on those indicators related to shift-work level. The measures rely on three assumptions. First, within the firm, labour is assumed to be organised in teams. Shifts follow, one upon the other and focus on the operation of a single piece of capital equipment. Second, since data relative to the hours of work of every worker within a particular team are often not available, we assume that weekly hours of work are identical among shifts, whatever the equipment considered. Third, capital intensities, which are associated with equipment $i$, are proportional to the capital intensity of the equipment operated by only one team. Also, these proportions are assumed to be constant. The weekly capital operating time indicator $\mathrm{COT}_{h}$ (Sylvain, 2004) is expressed as:

$$
C O T_{h}=h \times S W
$$


which is in line with models dealing with WTR and employment: $h$ is the average weekly hours of work for workers belonging to the team; $S W$ is the average number of shifts that operate the equipment within the establishment. Here, $S W$ is unknown. One solution is to consider that $S W$ refers to the number of workstations that are simultaneously occupied (Bosworth and Cette, 1995). The corresponding shift-work indicator is a harmonic mean of the $n_{i}$ shifts and $C O T_{h}$ can be rewritten as:

$$
\mathrm{COT}_{h}=\mathrm{COTH}_{h} \equiv h\left(\sum_{i=1}^{M} \frac{p_{i}}{n_{i}}\right)^{-1}
$$

where $p_{i}$ is the proportion of the workforce operating each piece of equipment $i$. Another solution would be to assume that the capital intensity of equipment where $n_{i}$ teams follow each other is equal to the capital intensity of non-shift-work equipment. Thus, the shift-work indicator is an arithmetic mean of the $n_{i}$ teams and $\mathrm{COT}_{h}$ is:

$$
\operatorname{COT}_{h}=\operatorname{COTA}_{h} \equiv h \sum_{i=1}^{M} n_{i} p_{i}
$$

Two things have to be mentioned. First, these indicators can also be computed for firms that do not make use of shift-work. For those companies, the organisation of the work is equivalent to a 'single- (or one-) shift organisation' where COT indicators will be equal to the average hours of day workers, i.e. those people who work ordinary time schedules (Lanfranchi et al., 2002). Second, within a given plant, the resulting COT indicators are good proxies for the weekly COT level in two cases: $(i)$ if the capital intensity is the same for all capital equipment; (ii) if there is only one kind of shift-work systems in place. Otherwise, COT is measured with error when using these indicators.

\section{Data and descriptive statistics}

In this section, we present data and some descriptive statistics that are related to the evolution in working times and COT over the time period when the French 35-hour work week was enforced. 


\section{Data}

The data are derived from merging the administrative files of WTR agreements (Direction de l'Animation de la Recherche, des Etudes et des Statistiques, DARES; French Ministry of Labour, May 2003) and the survey on COT in manufacturing industries (Banque de France, Central Bank of France; 1989-2004).

\section{The WTR agreement administrative files}

These data were collated by the DARES (French Ministry of Labour, May 2003). They are at establishment level, regardless of the size or type of business sector (private or public). The files contain information on over 468,000 productive units that decided to implement a WTR, within the framework of the adoption of Aubry 1 and 2 laws that aimed at reducing standard working hours. For all firms that decide to adopt the French 35-hour work week with the adoption of the Aubry reform on 13 June 1998 to May, 2003, we have information on the date that they signed a WTR collective agreement (day, month and year) and the date when the WTR became effective. We have information on the business sector of activity and the size of firms' workforces at the date when the agreement was signed. This dataset also contains information on the (few) firms that reduce the working time of their workers through the Robien law.

\section{The COT survey}

The COT survey has been yearly conducted by Banque de France since 1989 and is at firm level. It is managed by l'Observatoire des Entreprises and is realized thanks to the branches les Comptoirs de la Banque de France, which send questionnaires to firms and retrieve data. Every year, this survey provides information on some 1,500-2,500 companies coming from the manufacturing sector. 30 to $37 \%$ of the responding sample is renewed from one year to the following. Hence, Banque de France only follows some firms over time and only over couple of years. The survey asks for information on the way work is organised within the firm during the second week of September. 
The first part of the survey asks firms to identify their business sector of activity and the size of their whole full-time equivalent workforce, ${ }^{11}$ and for details of the organisation of work during the second week of September. The average weekly hours of work at the company level is an arithmetic mean of individual employees' hours of work. Then, one question asks firms whether or not it makes use of shiftwork. If no, the organisation of the work in a given company is equivalent to a 'single-shift organisation', where there are only day workers. If yes, the organisation of work is described in terms of different types of shift-work: discontinuous shift-work (two-shift organisation), semi-continuous shift-work (three-shift organisation) and continuous shift-work. A discontinuous or two-shift organisation is aimed at increasing COT, but allows the equipment concerned to be idle for a given period of time each day (usually during the night). In semi-continuous work schedules, three shifts of workers operate the same equipment, continuously on weekdays (the firm is closed on Saturdays and Sundays). Continuous shift-work adopts the same pattern but includes weekends, i.e. the capital equipment operates 24 hours a day, 7 days a week. The second part of the survey deals with the weekly or annual number of days when the capital equipment is idle, and the reasons for these non-productive times. The reasons for capital equipment being idle include mainly paid holidays, seasonal activity and public holidays.

The third part of the questionnaire asks companies for variation in their average weekly past (i.e. the previous 12 months) or future COT (i.e. the coming 12 months). It provides information on how the company has changed average weekly COT: increasing or decreasing intensity of shift-working; increasing or decreasing weekly hours of work; investing in new capital equipment; other ways (e.g. short-time working). This information is available only up to 2001.

The fourth part of the survey deals with the problems that the firm will have to resolve if the choice is to increase COT in the future. Indeed, it asks companies whether there are likely to be obstacles to increasing COT. For instance, such obstacles may be institutional obstacles (labour laws; some regulations). They may also refer to obstacles that are related to social relationships (reluctance of

\footnotetext{
${ }^{11}$ The workforce includes all of the firm's permanent and temporary employees.
} 
employed people; union attitudes) or to technological constraints (lack of skilled workers; bottlenecks in supply of raw materials; technical obstacles).

In a last part of the COT survey, firms were asked to what extent they can increase production using already installed equipment, with or without hiring new people. Through this information, we are able to get capacity utilisation rates.

\section{Final sample}

Our final sample is obtained by merging these datasets at the firm level. The WTR data set is built at the establishment level, and the COT survey at the firm level. In the WTR survey, one variable refers to the main establishment, i.e. "firm headquarters". The WTR dataset provides information on whether and when an establishment signed a WTR agreement. We check this date (year, month) is the same for the "head quarter" plant and all establishments that are part of a larger firm. Initially, our sample was made of 8,367 firms (30,588 firm-years). We then have to adjust our sample for several reasons. First, we restrain the sample to 1992-2002. Indeed, we do not consider firms covered by the first three years of COT survey (1989-1991) ${ }^{12}$; besides, as explained in sub-section 2.1, on 17 January 2003, the Fillon law was adopted, which, among other things, reduced the payroll tax cuts for WTR firms and increased them for other firms. After this step, there were 7,042 firms (22,618 firm-years). Second, we excluded all observations for which there were missing values (whole number of workers, hours of work, production margin - i.e. to what extent firms can increase production using already installed equipment, with or without increasing their workforce -, COT indicators, business sector of activity) when it was not possible to recover the information; ${ }^{13}$ we also drop observations with large values (weekly COT larger than 168 hours a week, production margin greater than 100 percent). Once this was done, there were 5,932 firms (17,369 firmyears) left that sign a WTR agreement (3,367 firms; 11,282 firm-years) or not. Third, we excluded

\footnotetext{
12 There was a break in the series between these years and the following (1992-2004). Hence, descriptive statistics on this time period dealing with COT indicators are not consistent with those over 1992-2004.

${ }^{13}$ For instance, when the whole number of workers was not available, we could sum the number of workers linked to each of the three shift-work systems and to day work. It was also possible to recover the information on the business sector of activity from the WTR survey when it was not available in the COT survey.
} 
particular companies: firms employing less than 20 people because they were covered by the COT survey

only up to 2000; few firms from other business sectors of activity than manufacturing (energy, shopkeepers, services) because they were not likely to be surveyed; firms who reduced working hours within the framework of the Robien law (11 June 1996 to 13 June 1998), firms that were not eligible for WTR payroll tax cuts (such as public sector companies) and firms created after 1 January $2000 .{ }^{14}$

We pooled repeated cross sections data for 1992-2002 and achieved a final dataset of an unbalanced panel of 4,850 firms (14,400 firm-years) that make use (3,264 firms or 8,952 firm-years) or not of shift-work. They signed (2,732 firms, i.e. 9,316 firm-years) or not a WTR collective agreement within the framework of the Aubry reform ${ }^{15}$.

\section{Evolution of hours of work and COT: 1992-2002}

\section{Implementation of the 35-hour working week in France}

First, we consider all firms that implemented a WTR between 13 June 1998 and May 2003 and which were part of the COT survey in the years 1992-2004. We want to pinpoint the timing of the 35 -hour shock event. Graph 1 depicts the cumulative distribution function of firms employing more than 20 workers that decided to implement the 35-hour working week. 1 January 2000 was the date that the standard hours of work were reduced for those firms. We can see that some $43 \%$ of them signed a WTR agreement before that date, and that a majority (85\%) had signed on by the end of December 2000; almost all WTR firms (more than 97\%) employing more than 20 workers signed before 1 January 2002. Including all manufacturing firms with over 20 employees that signed a WTR agreement within the Aubry reform, but were not surveyed by the COT survey confirms these facts. This shows that what happened in the COT survey in terms of adopting the 35-hour work week is representative of what happened at the whole French manufacturing industry.

\footnotetext{
${ }^{14}$ Contrary to other firms employing more than 20 workers, they could benefit from more tax cuts while implementing a WTR up to 1 January 2002. Anyway, there were a limited number of such firms in our samples.

${ }^{15}$ The final sample represents only $69 \%$ of firms (64\% of firm-years) of the overall firms over 1992-2002. However, this sample appears to be representative of initial sample, either distinguishing between WTR firms and non WTR firms. Tables containing descriptive statistics for the initial sample (either over 1989-2004 or 1992-2002) are available on request.
} 
Graph 1. Cumulative frequency of signing a Working Time Reduction agreement within the implementation of French the 35-hour work week.

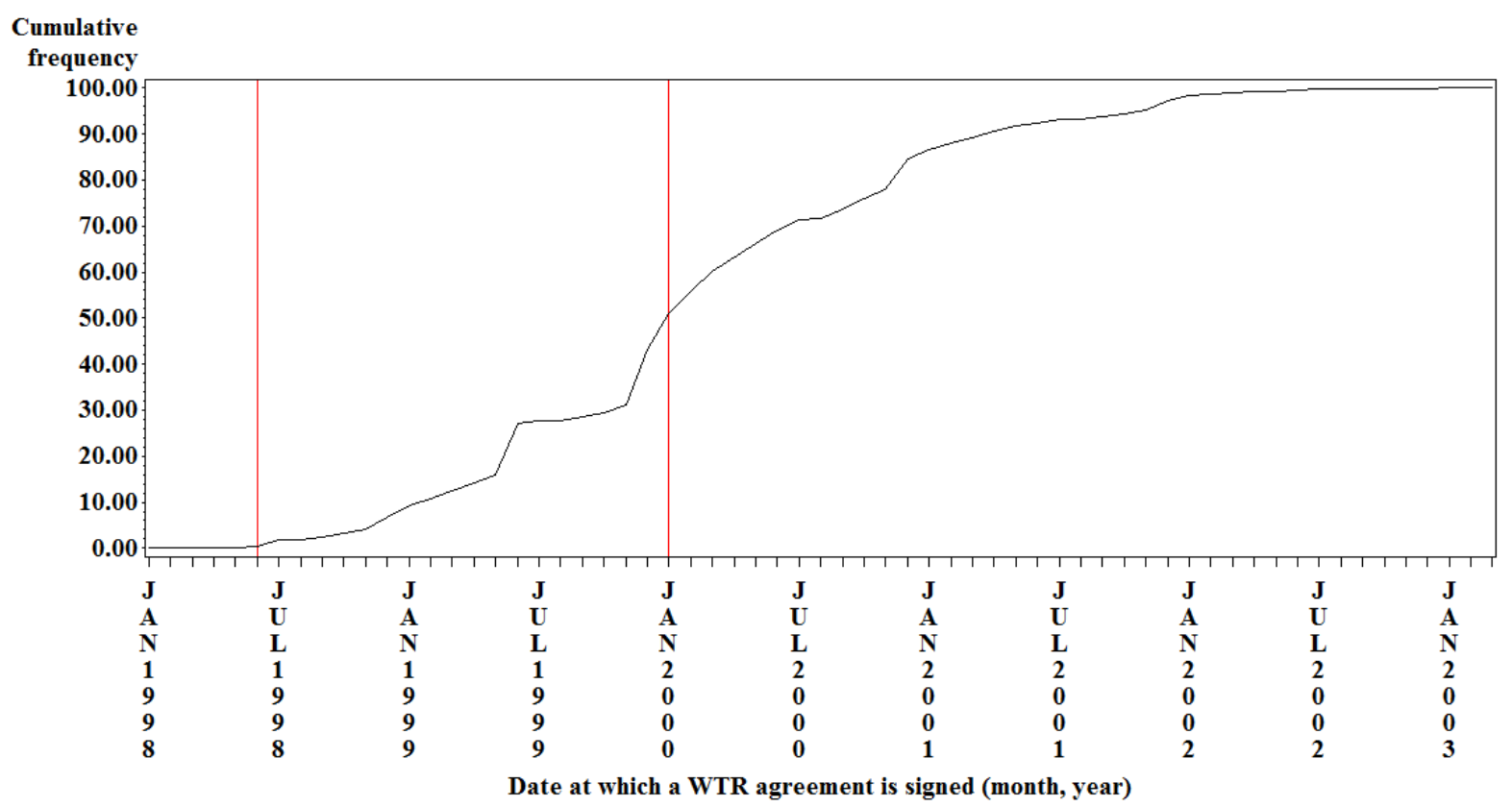

Source: French COT survey (Banque de France, 1992-2004) and administrative files of WTR agreements (DARES, French Ministry of Labour, 2003).

Field: 3,201 manufacturing firms (excluding the energy sector) with 20 employees or more that signed a Working Time Reduction agreement between June 1998 and June 2003.

Note: red bars indicate dates of implementation of Aubry 1 (June, 18 $8^{\text {th }}$ 1998) and 2 laws (January, 19 $\left.9^{\text {th }} 2000\right)$.

Second, we want to see by how much the effective weekly hours of work really decreased after the adoption of the French 35-hour working week. To look at the variation in the weekly hours of work over 1992-2002, we distinguish between firms that implemented a WTR and those that did not. We consider the variable available from the COT survey, i.e. average weekly hours of work at firm level, which is the arithmetic mean of employees' individual hours of work measured in the second week of September. The weekly working hours include breaks (for food, changes of clothing), as well as normal overtime working decided on through collective agreements; it does not include short-time working or absenteeism. Graph 2 shows that weekly working time have diminished in both WTR and non WTR firms. Between September 1992 and September 1997 working hours in both types of firms were the same (on average 38.8 hours a week). Since September 1997, working hours have decreased more in the former type than in the latter (on average 35.6 vs. 36.9 hours a week). The relative decrease in working hours in WTR firms relatively to other firms is less than four hours. 
Graph 2. Supplied Weekly Hours of work in France over the 1992-2002 time period, distinguishing firms that implement a WTR from other firms.

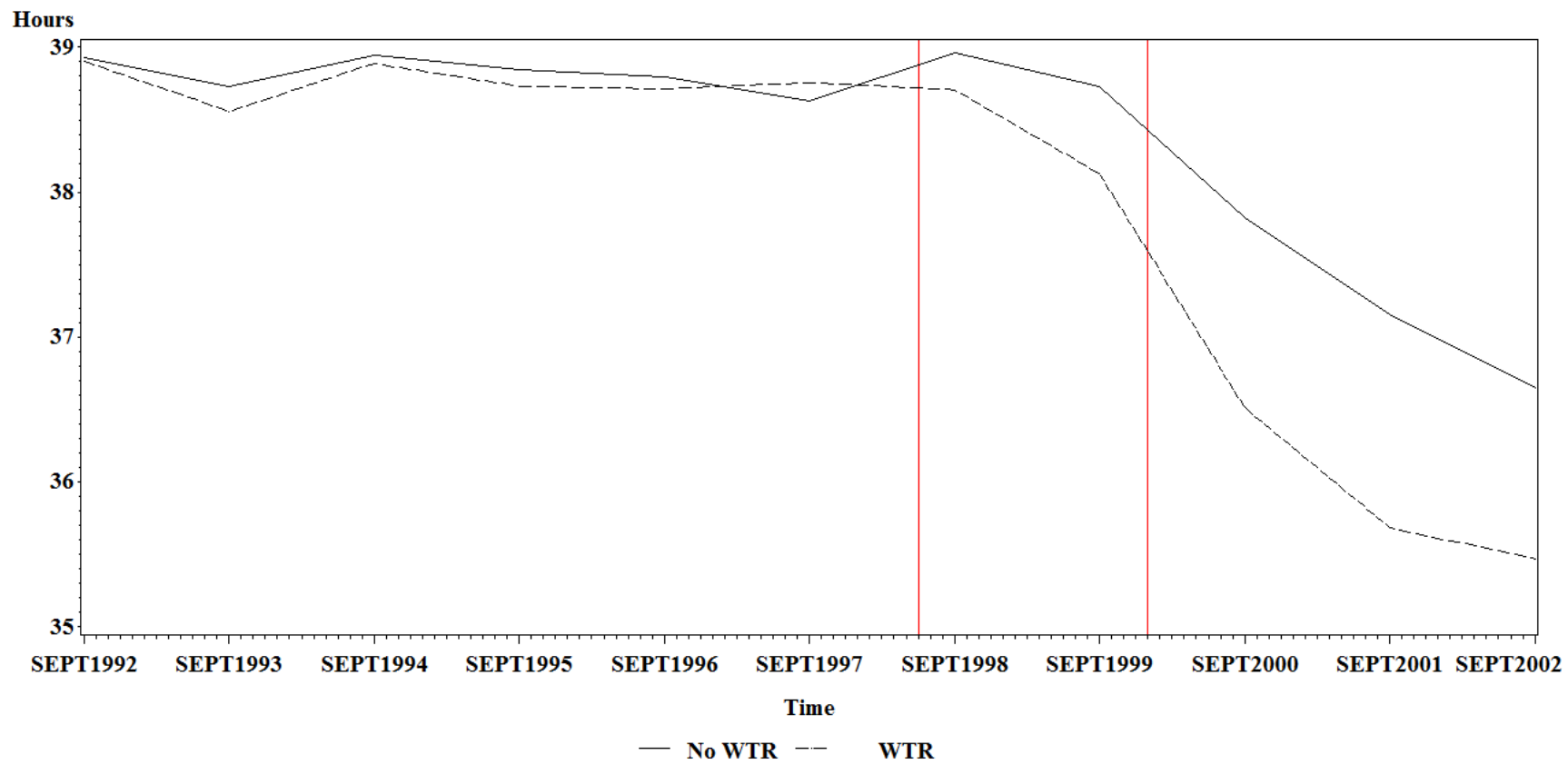

Source: French COT survey (Banque de France, 1992-2002) and administrative files of WTR agreements (DARES, French Ministry of Labour, 2003).

Field: 4,850 manufacturing firms (excluding the energy sector) with 20 employees or more that signed $(2,732$ firms) or not a Working Time Reduction agreement within the framework of the Aubry reform.

Note: red bars indicate dates of implementation of Aubry 1 (June, 18 $8^{\text {th }}$ 1998) and 2 laws (January, 19 $\left.9^{\text {th }} 2000\right)$.

Among firms that reduced the working time of their employees, only those that reduced effective working hours before standard hours were cut down to 35 hours benefit from more payroll tax cuts if they reduced the working hours by as much as 10 per cent. ${ }^{\mathbf{1 6}}$ In the case of other firms, the size of the WTR was reduced, for instance, by including production slack periods in computations of working time (Askenazy, 2008). The framework of the Aubry 1 and 2 laws allowed plants to compute the working hours of their employees on an annual basis.

\section{Variations in COT indicators}

Based on information available from the COT survey, and assuming that the continuous shift-work system refers to a five-shift system (Sylvain, 2004), we built the two indicators presented in the previous section for weekly COT. Graph 3 shows the evolution of the COT using an arithmetic mean based shift-

\footnotetext{
${ }^{16}$ In order to benefit from more tax cuts, they also had to commit to a $6 \%$ increase in employment (or maintenance of present levels if they plan to fire people before reducing the working time).
} 
work indicator, within WTR and non WTR firms, in 1992-2002. Weekly COT is larger in WTR firms, at least between September 1992 and September 1996 (on average: 55.8 vs. 53.1 hours), i.e. before implementation of the French 35-hour working week. In this period, the variation in COT is similar for both types of firms. In September 1997, there was a break and since then, in WTR firms COT seems to have increased or at least remained constant compared to other firms.

So far, we have discussed only the evolution in weekly COT. However, within the special framework of the French mandatory working time reduction, plants were allowed to compute the annual working hours of their employees. To get an annual indicator for $C O T_{a}$, we need data on COT, shift-work and employees' hours of work, for every working week across a 12 month period. We do not have this information. As an alternative we can write $C O T_{a}=N B W \times C O T_{h}$ where $N B W$ is the number of weeks the establishments (of a given firm) are open and producing, across the period of a year. $N B W$ can be computed using through the information - up to 2001 - provided by the COT survey, on the number of days a year when productive units are closed (for paid holidays, public holidays, seasonal activities or other reasons). Graph 4 shows the evolution of the annual COT indicators. Annual COT is higher in WTR firms than in other firms (on average: 2,096 vs. 1,940 hours ${ }^{17}$ ). Otherwise, the weekly findings hold for annual COT.

\footnotetext{
${ }^{17}$ Previously, we mention 1,820 and 1,600 that refer to the old and new annual standard hours of work, i.e. before and after January, $1^{\text {st }} 2000$. Hence, these figures are not necessarily equal to the values taken by annual COT indicators. For instance, it may be the case if the standard and the effective hours of work are equal and if there is only a single- or one-shift system within the plant. In this case, the ratio of COT indicators to these (standard) hours of work are by construction equal to the number of shifts before (or after) the implementation of the Aubry reform (see sub-section 3.3).
} 
Graph 3. Evolution of WEEKLY capital operating time over the 1992-2002 time period, distinguishing firms that implement a WTR from other firms. Using an arithmetic mean as an indicator for shift-work.

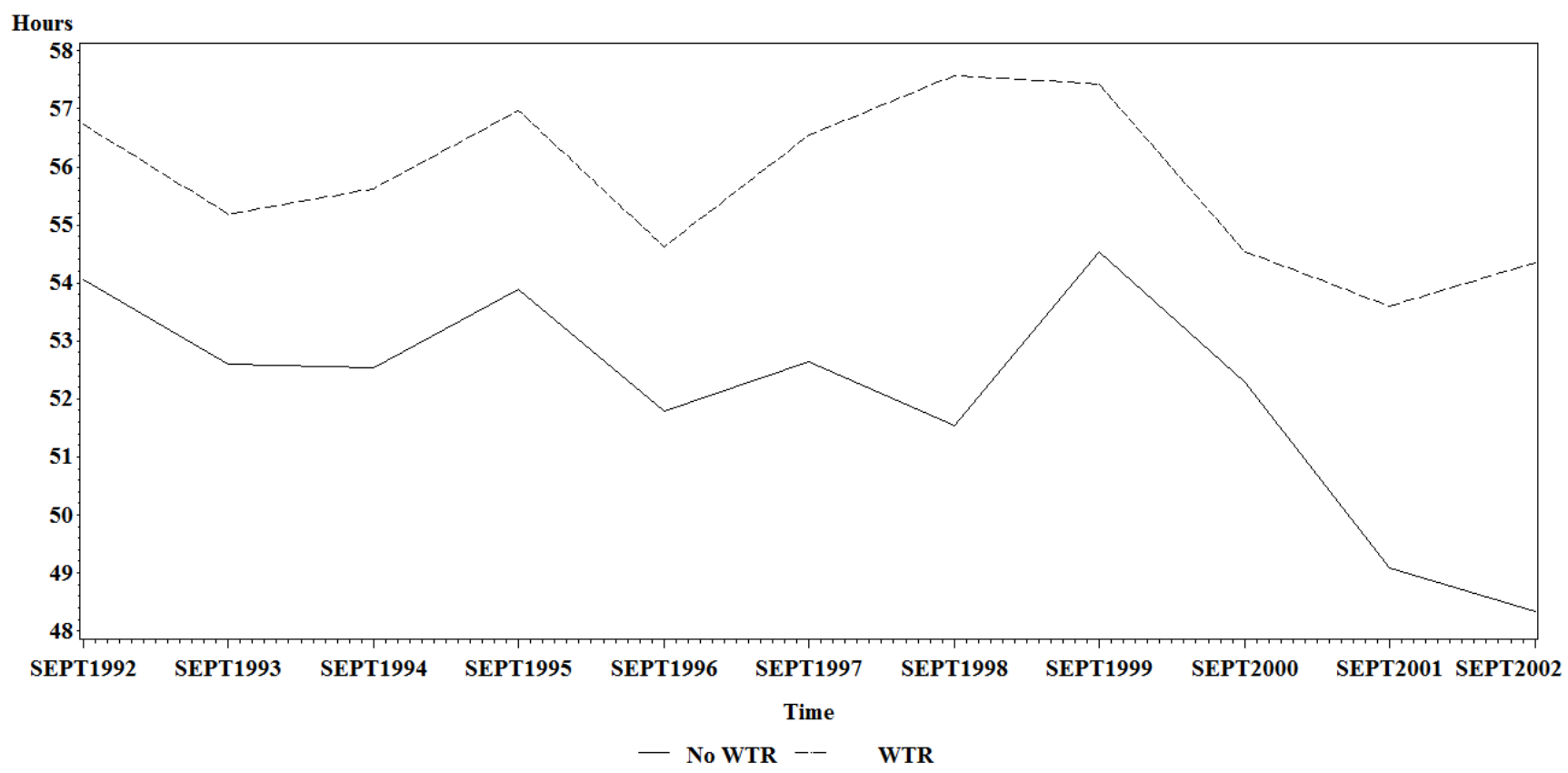

Source: French COT survey (Banque de France, 1992-2002) and administrative files of WTR agreements (DARES, French Ministry of Labour, 2003).

Field: 4,850 manufacturing firms (excluding the energy sector) with 20 employees or more that signed $(2,732$ firms) or not a Working Time Reduction agreement within the framework of the Aubry reform.

Otherwise, the same conclusions can be made using the harmonic mean COT indicator. ${ }^{18}$ Finally, we have to mention that the same patterns (graphs and figures) are observed if we consider as WTR firms only those that sign an agreement before 1 January 2001 although they only represent $85 \%$ of manufacturing firms.

To conclude, we can say that weekly and annual COT may have increased or at least remained unchanged in WTR relative to other firms. But is this a consequence of the introduction of a 35-hour working week?

\footnotetext{
${ }^{18}$ As mentioned in sub-section 2.3, the harmonic mean based COT indicator takes smaller values than the arithmetic one. It still shows larger COT values in WTR firms than in non WTR firms, either considering weekly (49.2 hours vs. 47.8 hours, over 1992-1996) or annual (1,816 vs. 1,727 hours) COT.
} 
Graph 4. Evolution of ANNUAL capital operating time over the 1992-2001 time period, distinguishing firms that implement a WTR from other firms. Using an arithmetic mean as an indicator for shift-work.

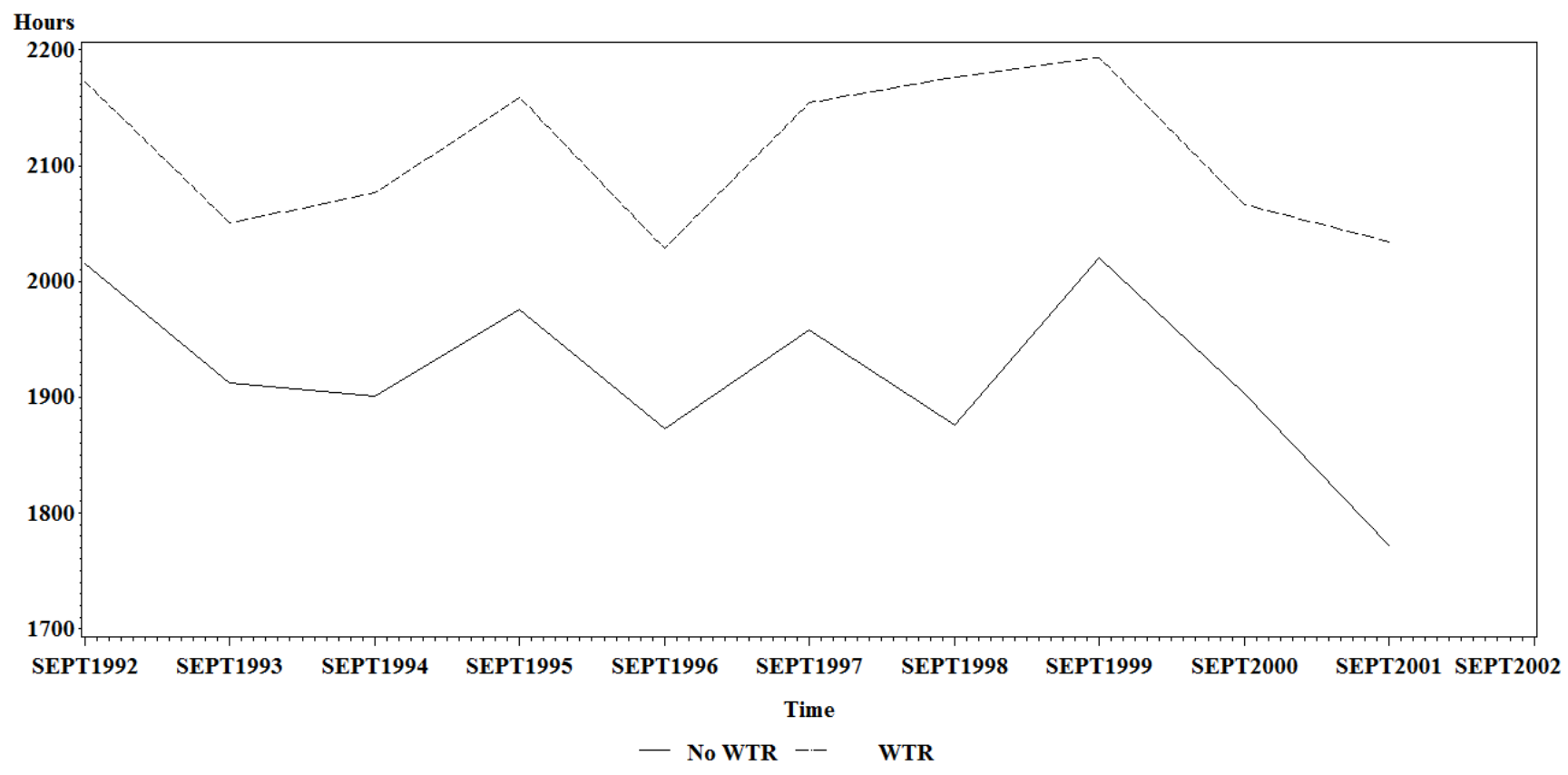

Source: French COT survey (Banque de France, 1992-2002) and French administrative files of WTR agreements (DARES, French Ministry of Labour, 2003).

Field: 4,850 manufacturing firms (excluding the energy sector) with 20 employees or more that signed (2,732 firms) or not a Working Time Reduction agreement within the framework of the Aubry reform.

\section{Identification strategy}

To estimate the impact of the French 35-hour working week on COT, we have to cope with selection bias.

This section describes our identification strategy, considered the estimators and lists covariates, i.e. the observed variables that might affect both WTR implementation and COT.

\section{Identification}

\section{The evaluation model}


To estimate the impact of the 35-hour work week on COT in France, we use the model proposed by Rubin [1974]. Within the framework of the Aubry 1 and 2 laws, we compute the effect of a WTR on those firms that effectively implemented it. In other words, our purpose is to evaluate to what extent WTR firms vary their COT following the implementation of a WTR in comparison to what would have happened had they not implemented any WTR. This is the Average Treatment effect on the Treated (ATT), $E\left(Y_{1}-Y_{0} \mid T=1\right)$, where $Y$ is the (logarithm of the) level of the COT indicator and $T=1$ corresponds to the group of firms that implement the 35-hour working week (treatment group), while $T=0$ refers to the group of firms that do not adopt any WTR (control group). As usual, the COT level in the once the WTR is adopted is $\left(Y_{1}\right)$ is observed for the group of WTR firms, while that in the absence of the policy $\left(Y_{0}\right)$ is counterfactual, i.e. is never observed for those companies.

The implementation of a WTR is not random and the differences in COT between WTR firms and other firms may be due to other factors. To get unbiased estimates, we need to control for selection bias on the observed and unobserved variables (Heckman et al., 1998).

\section{Econometric method: FE vs IV}

The firm can choose to implement or not a WTR. Hence, $T$ is endogenous. Thus, those companies are particular (Bunel, 2004; Gilles, 2006). At least, to get a good estimate of ATT, two types of bias have to be controlled for (Blundell and Costa Dias, 2009). The first refers to selection on observed variables and may be controlled for by including in the COT equation all the covariates, i.e. the observed variables that determine both the implementation of the WTR and COT. The second refers to selection on unobserved variables. Even if we control for bias on observed variables, ATT estimates may still be biased because of unobserved heterogeneity. The econometric method commonly used to solve this problem is Instrumental Variables (IV). However, to identify $A T T, I V$ requires that we find at least one observed variable that affects the implementation of WTR by the firm, but not COT. Finding this variable can be difficult 
(Heckman, $\left.1976^{19}\right)$. In some cases, when longitudinal or repeated cross sections data are available, Fixed Effects $(F E)$ or Differences-in-differences $(D I D)$ can be used. The unobserved heterogeneity is modelled as an unobserved firm variable that is time-invariant (Angrist, 2010). It may include variables on which we do not have information, such as: technical obsolescence of equipment (Betancourt and Clague, 1981; Oi, 1981); production returns to scale (Betancourt and Clague, 1981; Bosworth and Heathfield, 1995); share of women in the firm's workforce (Bosworth et al., 1981; Foss, 1997); average age of workers (Bosworth et al., 1981; Bosworth and Heathfield, 1995). However, the model identifies ATT only if, without implementation of the French 35-hour working week, in firms that introduced a WTR, COT would have evolved in the same way as in firms that did not introduce any WTR (Heckman et al., 1998).

\section{Differences-in-differences within the context of the Aubry reform}

To check the common trend assumption, we compare the variations of COT in WTR and non-WTR companies before the 35 hour shock. With regards to the timing of the Aubry reform, we can identify three time periods between 1992 and 2002, for before, during, and after the working time regulation. First, as mentioned in sub-section 3.1, the Aubry 1 law was adopted on 13 June 1998 and the Aubry 2 law on 19 January 2000. Moreover, the initial discussions related to the adoption of the laws were held in 1997 (Askenazy, 2008; Les rapports du Sénat, 1997). Hence, to take account of the fact that firms might have anticipated the adoption of the Aubry laws, we consider that the period of the shock began in 1997. Second, in sub-section 3.2, we show that most firms (85\%) employing more than 20 workers signed a WTR agreement by the end of December 2000 and almost all WTR firms (more than 97\%) signed on before 1 January 2002. In order to have a large enough sample of firms after the 35 hour shock to evaluate its impact using a before-after strategy with a treatment and a control group, we excluded all firms that implemented a WTR after December 2000. Therefore, we consider that the period of the shock was 1997 2000, before the shock refers to 1992-1996, and after the shock is 2001-2002. ${ }^{20}$ Third, for our purpose

\footnotetext{
${ }^{19}$ In particular, the instrumental variable may not be sufficiently correlated with the endogenous variable (weak instrument). On the other hand, it has to be uncorrelated with the residual of the structural equation, which cannot be tested (Wooldridge, 2003).

${ }^{20}$ Excluding firms that signed an agreement in 2001 leads to a reduction of 12 percent of the number of WTR firms in our
} 
(estimating DID), we only use before and after observations. Indeed, we drop all firms that are observed on the period of the shock: they are likely to contaminate our results. Our estimations of ATT are thus made on a sample of 3,376 firms (or 8,217 firm-years) with at least 20 employees, that signed (1,676 firms or 4,701 firm-years) or not a WTR agreement between June 1998 and December 2000.

Since we use a rotating panel (resulting from repeated cross sections), we need to know the proportions of firms by number of times they are observed. This is particularly important because not all the firms are observed at the same time.

Table 0. Proportions of firms by number of times they are observed in the sample, following the type of firms under consideration.

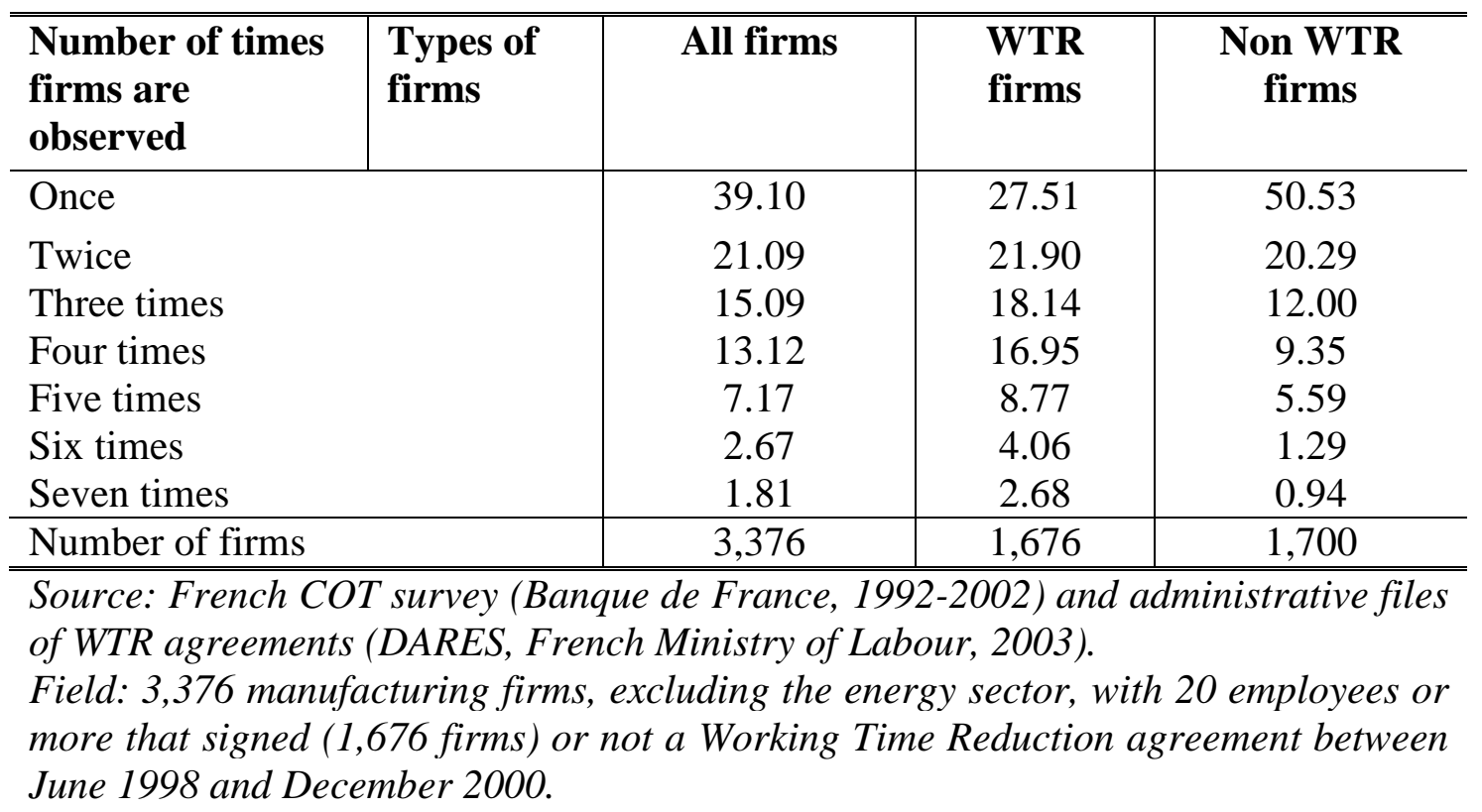

As expected (Table 0), most are either observed once, twice or three times. Moreover, non WTR firms are observed only once, more often than other firms because they are smaller.

What may be also interesting to know is the proportion of firms that are observed both before and after the regulation. Overall, whereas all 3,376 firms were observed at least once before the regulation, only 709 firms were both observed before and after the regulation. Among them, there were 532 firms that sign a WTR.

sample. Thus, as a robustness check, we will also consider those firms; in that case, the period of the shock is 1997-2001, and the period after the shock is 2002 . 
Table 1. Testing for a common trend in the absence of the Aubry reform in the growth rates of Capital Operating Time in companies that implement a WTR and in other firms.

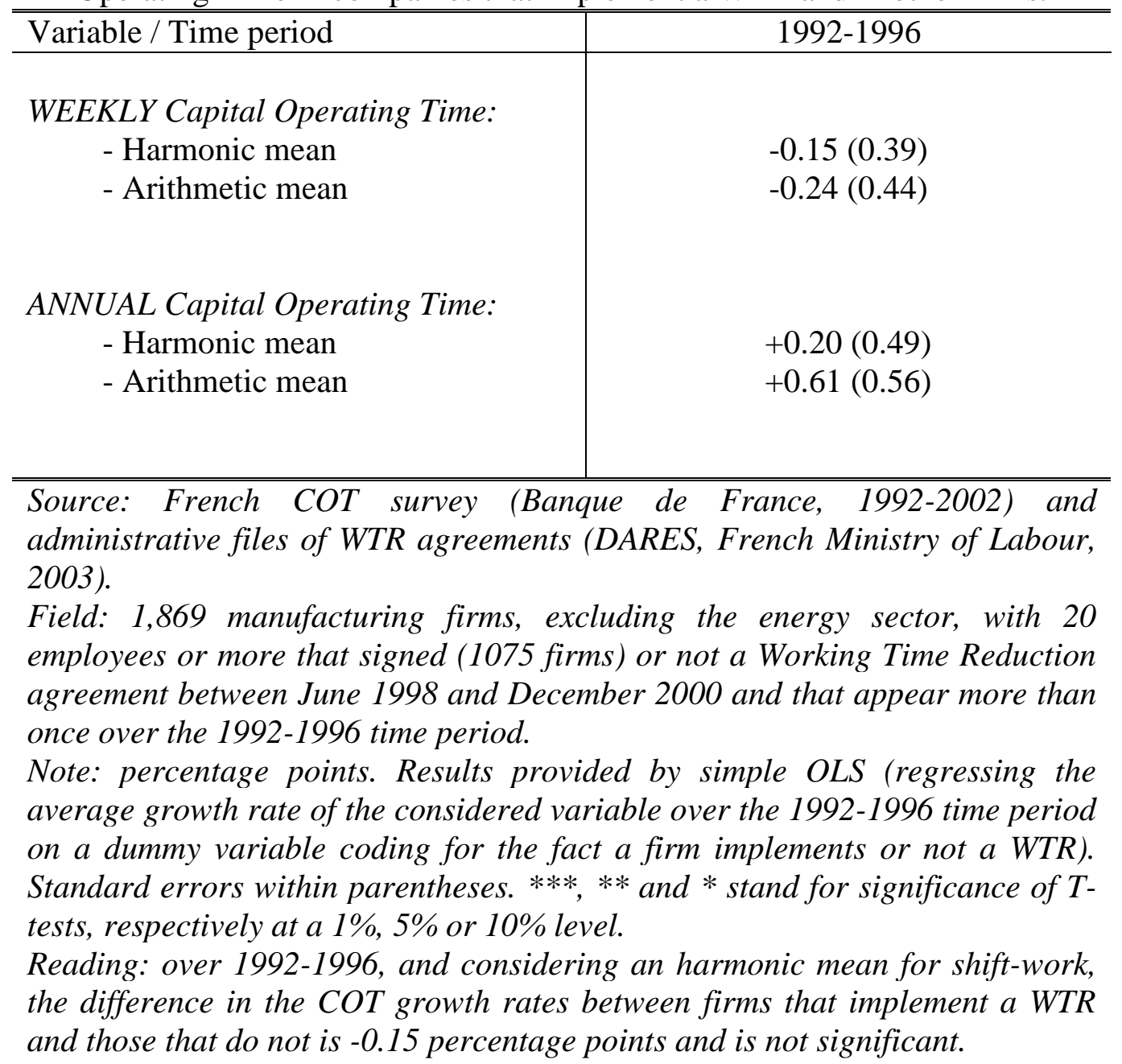

To test the same time trend assumption, we regress the individual average growth of COT over 19921996 on an intercept and a dummy that refers to the status of the companies relative to the 35-hour working week. Table 1 shows there are no differences between the two types of firms, whatever COT indicator is used. ${ }^{21}$ This confirms the intuition from Graphs 3 and 4 . Hence, we can consider the $F E$ model and apply differences-in-differences (DID) estimators to evaluate the impact of the 35-hour working week in France.

\section{Conditional DID estimators using repeated cross sections}

Since the same time trend assumption is verified, we apply conditional differences-in-differences (DID) estimators, i.e. Before - After estimator with control and treatment groups, to our repeated cross sections

${ }^{21}$ As an alternative, we ran the same type of regression, but reweighted by the lagged COT level. The results were unchanged. 
dataset. Our data design refers to the situation where samples are drawn from the same population before and after the intervention being studied. Wooldridge (2003) studies the case of DID applied to independent repeated cross sections. Lee and Kang (2006) consider DID in the case of repeated cross sections where some individuals are observed both before and after the policy enforcement ("rotating panel" or "unbalanced panel with movers"). In this case, linear DID estimators of ATT are provided by running the following regression (Abadie, 2005):

$$
Y_{i, t}=\mu+\alpha t_{i}+\lambda T_{i}+\delta \theta_{i}+\beta_{P, R C S} D_{i}+\pi X_{i}+\varepsilon_{i, t}
$$

where $Y_{i, t}$ indicates the logarithm of COT; $X_{i}$ refer to predetermined covariates and $t_{i}$ are time dummies; ${ }^{22} T_{i}$ says whether $\left(T_{i}=1\right)$ or not $\left(T_{i}=0\right)$ a firm implements a WTR over $(t=1998-2000) ; \theta_{i}$ indicates whether firm $i$ is observed after $\left(\theta_{i}=1\right)$ or before $\left(\theta_{i}=0\right)$ the 35 hour shock; and $D_{i}$ is the product of $T_{i}$ with $\theta_{i}$; OLS $\hat{\beta}_{P, R C S}$ is the estimated $A T T$. To proceed, in our sample, we distinguish between four types of companies, two before the shock and two after the shock. $N_{1,1992-1996}$ (respectively $N_{0,1992-1996}$ ) companies are observed at time $t \in[1992 ; 1996]$ and do (respectively do not) implement a WTR between $t=1998$ and $t=2000 . \quad N_{1,2001-2002}$ (respectively $N_{0,2001-2002}$ ) companies are observed at time $t \in[2001 ; 2002]$ and do (respectively do not) adopt a WTR between $t=1998$ and $t=2000$. To get $\hat{\beta}_{P, R C S}$, we pool all those observations and run OLS on equation (5).

However, this ATT estimator relies on certain assumptions. First, equation (5) implies a linear relationship between $Y_{i, t}$ and the covariates $X_{i}$. Second, this estimator is not necessarily computed on comparable firms. In particular, it makes use of all firms to evaluate ATT and, hence, may not be consistent. These two restrictions may be relaxed using differences-in-differences models combined with propensity score matching estimators (Blundell and Costa Dias, 2009; Rosenbaum and Rubin, 1983):

\footnotetext{
${ }^{22}$ They are assumed to take account of the economic situation at the time where $X_{i}$ is observed (over the before time period).
} 


$$
\hat{\beta}_{S P, R C S}=\frac{1}{N_{1,2001-2002}} \sum_{i=1}^{N_{1,2001-2002}}\left\{Y_{1, t, t}-\left[\sum_{j=1}^{N_{0,2002-2002}} \omega(i, j) Y_{0 j, t}-\sum_{j=1}^{N_{1,1992-19966}} \omega(i, j) Y_{1 j, t}+\sum_{j=1}^{N_{0,1902-19966}} \omega(i, j) Y_{0 j, t}\right]\right\}
$$

$\omega(i, j)$ are positive weights. They depend on the propensity score $P\left(X_{i}\right) \equiv P\left(T_{i}=1 \mid X_{i}\right)$, i.e. the conditional probability to implement a WTR, and are given using the Nadaraya Watson estimator:

$$
\omega(i, j) \equiv \frac{K\left(\frac{P\left(X_{i}\right)-P\left(X_{j}\right)}{h_{N_{T, t}}}\right)}{\sum_{j=1}^{N_{T, t}} K\left(\frac{P\left(X_{i}\right)-P\left(X_{j}\right)}{h_{T, t}}\right)}
$$

where $K$ is a kernel function (Heckman et al., 1998). From a practical point of view, semi-parametric estimations are obtained in three steps. In the first, the propensity score is estimated using a parametric model. In the second, the three weighted means are estimated for each treated company $i$ at time $t \in[2001 ; 2002]$. In the third, the conditional DID estimates are deduced.

\section{Covariates}

These are provided in the literature on COT determinants. They may be correlated with the implementation of a WTR. Table 2 reports descriptive statistics for these variables over the whole sample and for every type of firm. ${ }^{23}$

(i) Capital intensity. A priori, the COT level is higher when the company has a larger capital-to-labour ratio. Increasing COT allows the firm to economise on capital. The higher the cost of the equipment associated with a work-station, the more likely it is that the employer, who takes account of the existence of specific costs related to shift-work (such as the shift-work premium), will use shift-work intensively (Cette et al., 1986). Table 2 shows that implementing the 35 -hour work week is correlated with the business sector of activity. WTR firms are more frequent in the agricultural and food industries, and in shipbuilding, aircraft and train construction, mechanical equipment, electrical and electronic equipment, mineral products, textiles and chemistry, rubber and plastics.

\footnotetext{
${ }^{23}$ The final column in Table 2 reports the differences in covariates for the two types of companies. Otherwise, Table A1 in appendix mentions all the variables that are used and their definition.
} 
(ii) Size of the firm's workforce. In a given business sector, shift-work should a priori be more frequent, and the COT level should be higher in companies that employ larger numbers of people. Relative to other firms, big firms are more likely to have the administrative services and the experience required for a sometimes complex organisation of work into successive shifts (Bosworth and Cette, 1995; Cette et al., 1986; Oi, 1981). Table 2 shows that WTR firms are larger.

(iii) Social and institutional environment. A particular firm may or may not be able to adopt some level of reorganisation. It may depend on a more or less contentious relationship between unions and employers. Indeed, unions with more bargaining power are more likely to create limitations to expending shift-work among unionised workers - especially if it will result in unsocial working hours (such as late shifts or nightshifts) and pace of work (Bosworth et al., 1981). Table 2 shows that companies that implement a WTR are more likely to face resistance from their employees, and that a heavily unionised workforce will be an obstacle to increasing the level of COT in those firms.

(iv) Cyclical and structural determinants of COT. The COT survey contains information on variations to the subjective weekly COT averaged over the year before the date of the survey. However, we do not use this indicator, because it is subjective and, hence, assumes that employers have perfect knowledge of COT, and is characterised by mass points. However, we do consider what makes it vary, i.e. the structural determinants of COT (Sylvain, 2001). The employer declares whether or not the variation in this subjective indicator is obtained through a variation in overall shift-working using already installed equipment, or in the weekly hours of work through investment in new capital equipment or through the use of short-time working. On the other hand, keeping the level of installed equipment unchanged, COT can vary on the basis of cyclical determinants that are reflected in capacity utilisation rates with or without new hires (Sylvain, 2001). Using a model of the discrete choice of the organisation of work in one or two successive teams, Mayshar and Halevy (1997) show that when the demand for goods increases (diminishes) the firm has an interest in increasing the size of the installed shift or overtime working 
(short-time working). Also, if the increase in demand is large enough, the company will have an interest in introducing another shift, which may be related to the implementation of a new organisation.

These theoretical results have been confirmed by empirical works (Shapiro, 1993; Mayshar and Solon, 1993). Alternatively, the firm may bring into use previously idle equipment and increase its workforce level. Table 2a shows that capacity utilisation rates were higher in WTR firms before implementation of the 35 hour working week and that these firms are more likely to change the COT through the use of shift-work or investment in new capital equipment.

(v) Number of days when the capital equipment is idle. ${ }^{24}$ The length of time in a week when the capital equipment is not in operation is a priori negatively correlated with the level of the COT indicators computed in the previous section. This time is likely to affect the weekly and annual COT (although the latter to a lesser extent), as reported by Bresnahan and Ramey (1994) and Hall (2000). Both studies note that the number of days when capital equipment is idle may be responsible for a large part of the variation in the weekly COT. The number of days when the firm is closed over a normal week or the whole year, may contribute to the organisational constraints that the company suffered before implementation of the French 35-hour working week. These constraints are likely to affect the firm's decision to reduce the working time of its employees. Indeed, before implementation of the French 35-hour working week, WTR companies were not productive for a longer period of time during the week than other firms.

Table A2 in appendix shows that all these variables also clearly distinguish shift-work firms and non shift-work firms. For instance, shift-work firms are less frequent in the agricultural and food industries, and clothing and leather, home equipment, mechanical equipment or electrical and electronic equipment. Moreover, they are larger than other firms. They are productive over a shorter period of time during the week than other firms. Besides, they are characterized by larger capacity utilisation rates and more often face obstacles when considering the possibility to increase COT. ${ }^{25}$

\footnotetext{
${ }^{24}$ These control variables are not used for annual COT indicators.

${ }^{25}$ The same conclusions hold as for Table A2 if we distinguish WTR form non WTR firms. Tables are available on request.
} 
Table 2. Descriptive statistics dealing with control variables.

Following the firm implements or not a WTR through the Aubry reform.

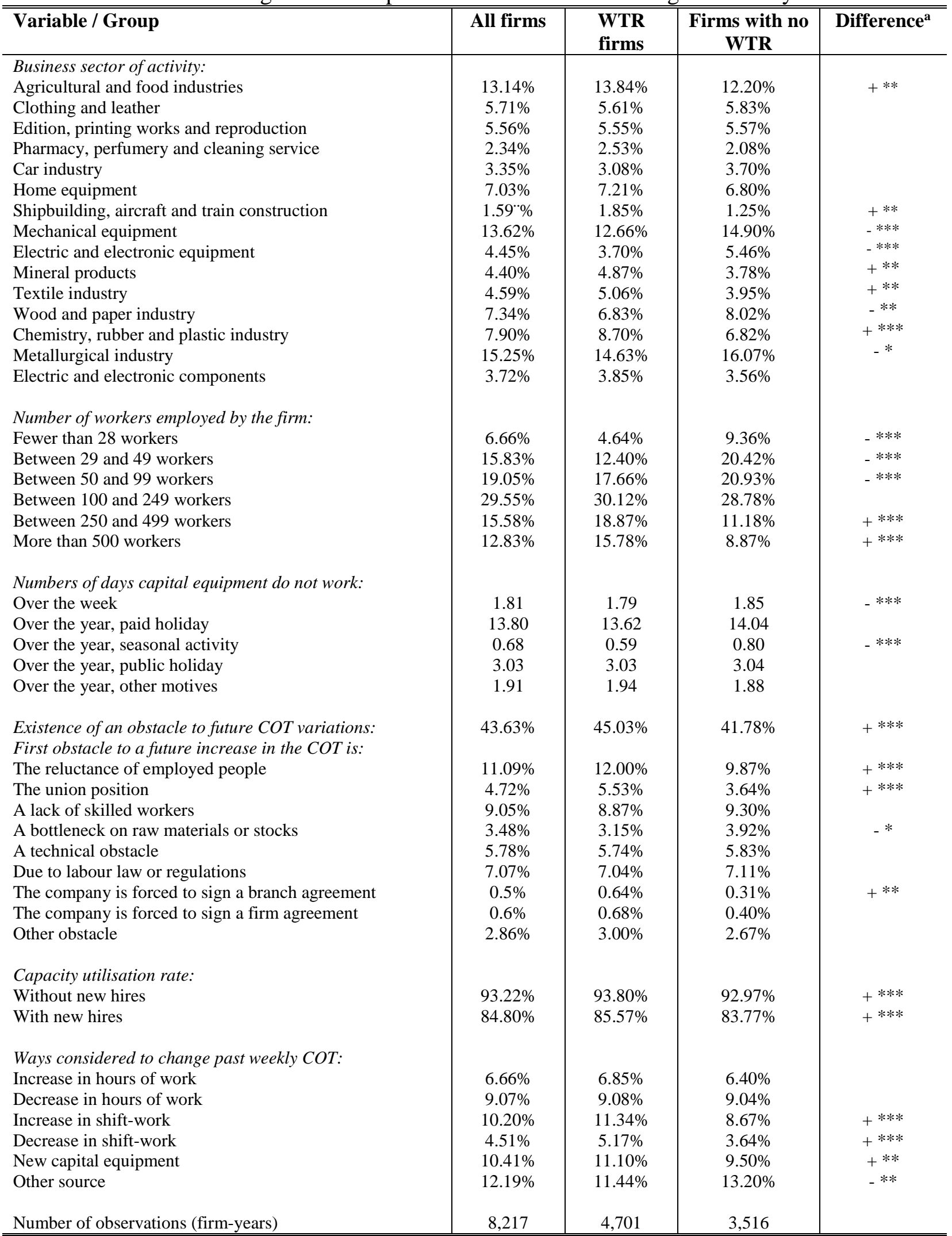

Source: French COT survey (Banque de France, 1992-2002) and administrative files of WTR agreements (DARES, French Ministry of Labour, 2003).

Field: 3,376 manufacturing firms, excluding the energy sector, with 20 employees or more that signed (1,676 firms) or not a Working Time Reduction agreement between June 1998 and December 2000.

Reading ${ }^{a}$ : for the last column, '+**' means that at a 5\% level, firms which operate in agricultural and food industries more often implement a WTR than other firms. ***,** and * stand for significance of T-tests, respectively at a $1 \%, 5 \%$ or $10 \%$ level. 


\subsection{Heteroscedasticity: measurement errors, serial correlation and clustering}

Since our goal is to evaluate whether or not the effect of the working time regulation on capital operating time is statistically significant, it is important to compute robust standard errors of estimators.

As mentioned in sub-section 2.3, our two main capital operating time indicators (COTA and COTH in (3) and (4)) are good proxies for the weekly COT level if either capital intensity is the same for all capital equipment, or only one shift-work system is in place within the whole plant. Hence COT is measured with error. Since COT is the dependent variable, OLS estimators are unbiased and consistent. However, applying OLS to the model replacing the true dependent variable with the dependent variable that is measured with error gives standard deviations for estimators that are mechanically greater (Wooldridge, 2003). The same issue holds when the dependent variable is in logarithmic form. Nevertheless (Wooldridge, 2010), the usual OLS inference procedures $(t, F$, and $L M$ statistics) are still valid.

Besides, another question that may be asked is whether or not there is heteroskedasticity in our model that will be due to any clustering or serial correlation. Both may be relevant because firms are sometimes of the same size or come from the same business sector of activity, and because we work with an unbalanced panel of firms. Thus, in semi-parametric estimates, we take account for the structure in the residual of the wrong model, by bootstrapping standard errors and confidence intervals. In the linear model, we display robust or clustered standard errors.

\section{Results and discussion}

This section presents the results of the impact of the 35-hour working week on COT and, hence, on shiftwork and hours of work. 


\section{Unconditional DID}

First, we look at the unconditional DID estimates. ${ }^{26}$ Graphs 3 and 4 show that COT may have increased in firms that adopted a WTR relative to other firms. Based on our final sample, we show that there is no significant rise in weekly COT with the implementation of the 35-hour working week, in 1992-2002 in WTR firms relatively to other firms (Table 3). This holds also for annual COT and reflects the superposition of two effects. On the one hand, weekly hours of work decrease more in WTR companies than in other firms. On the other hand, shift-work intensity increases more in WTR firms relative to other companies. However, this relative evolution may not be due to the 35 -hour working week. There are several factors that may have affected COT and implementation of the WTR.

\section{Conditional DID}

To examine the impact of the French 35-hour work week on COT, we use conditional DID estimators, controlling for covariates (Sub-section 4.3). Table 4a reports the results for the linear and propensity score (PS) matching DID estimates of equations (5) and (6) respectively. ${ }^{27}$ Matching on the log odd ratio (LOR) is used as robustness estimation to control for choice-based sampling (Heckman and Todd [2008]) using equation (6).

\footnotetext{
${ }^{26}$ In our model, $Y_{i, t}$ refers to the logarithm of COT. The DID estimator corresponds to the percentage points difference between the outcome growth rates (between 1992-1996 and 2001-2002 or 2001) that are measured in the two groups of firms (that implemented a WTR or not).

27 For the covariates $X_{i}$, we consider pre-determined variables that are observed at time $t \in[1992 ; 1996]$, before implementation of the 35-hour working week. When the considered firm is observed at time $t \in$ [2001;2002], we use the information about $X_{i}$ that is related to the first time $t \in[1992 ; 1996]$ at which the firm appears in the COT survey. If this is not possible, we exclude the considered company from the final sample. Along with $X_{i}$, we also control for year dummies to take account of the economic situation at the time $X_{i}$ is observed.
} 
Table 3. Growth rates of Capital Operating Time between before and after the adoption of the Aubry reform: differences between companies that implement a WTR and other companies.

\begin{tabular}{|c|c|}
\hline Variable / Comparison & 2001-2002 vs. 1992-1996 \\
\hline $\begin{array}{l}\text { WEEKLY Capital Operating Time: } \\
\text { - Harmonic mean } \\
\text { - Arithmetic mean }\end{array}$ & $\begin{array}{l}+0.57(1.96) \\
+2.92(2.61)\end{array}$ \\
\hline $\begin{array}{l}\text { Supplied weekly hours of work: } \\
\text { Shift-work: } \\
\text { - Harmonic mean } \\
\text { - Arithmetic mean }\end{array}$ & $\begin{array}{l}-3.78^{* * *}(0.38) \\
+4.34^{* *}(1.93) \\
+6.70^{* * *}(2.60)\end{array}$ \\
\hline Variable / Comparison & 2001 vs. $1992-1996$ \\
\hline $\begin{array}{l}\text { ANNUAL Capital Operating Time: } \\
\text { - Harmonic mean } \\
\text { - Arithmetic mean }\end{array}$ & $\begin{array}{l}+1.69(3.29) \\
+4.16(4.20)\end{array}$ \\
\hline $\begin{array}{l}\text { Number of weeks capital equipment } \\
\text { work over a whole year }\end{array}$ & $+1.75(1.33)$ \\
\hline $\begin{array}{l}\text { WEEKLY Capital Operating Time: } \\
\text { - Harmonic mean } \\
\text { - Arithmetic mean }\end{array}$ & $\begin{array}{l}-0.06(2.57) \\
+2.41(3.40)\end{array}$ \\
\hline $\begin{array}{l}\text { Supplied weekly hours of work: } \\
\text { Shift-work: } \\
\text { - Harmonic mean } \\
\text { - Arithmetic mean }\end{array}$ & $-3.90^{* * *}(0.50)$ \\
\hline
\end{tabular}

Source: French COT survey (Banque de France, 1992-2002) and administrative files of WTR agreements (DARES, French Ministry of Labour, 2003).

Field: 3,376 manufacturing firms, excluding the energy sector, with 20 employees or more that signed (1,676 firms) or not a Working Time Reduction agreement between June 1998 and December 2000.

Note: figures are expressed in percentage. Results are provided by estimating equation (5), without controlling for any covariates (unconditional DID estimates). $* * *, * *$ and $*$ stand for significance levels respectively at $1 \%, 5 \%$ or $10 \%$. Standard errors stand within parentheses.

Reading: between 1992-1996 and 2001-2002, weekly hours of work decreased by $3.78 \%$ in firms that implement a WTR in comparison to other firms. 
First, we look at the control variables. In the case of linear DID, as expected, we see that several factors other than implementation of a WTR explain COT (workforce size, business sector of activity, social and institutional environment, capacity utilisation rates, days off per year or week; Table A3 in appendix ${ }^{28}$ ). Considering the results of the propensity score's estimation (Table A4 in appendix ${ }^{29}$ ), ceteris paribus, the estimated coefficients confirm the descriptive statistics in Table 2. Hence, controlling for covariates is crucial to get the impact of the 35-hour working week on COT.

Second, with regard to the estimation of the effects of the French 35-hour working week, linear parametric and propensity score matching ${ }^{30}$ DID provide fairly similar results. Both methods show that weekly as well as annual COT remains stable after reduction in the working time, in WTR firms relatively to other firms. ${ }^{31}$ This means that the implementation of the French 35 hour-work week let COT unchanged in WTR firms. We have to remember that COT indicators are the product of our shift-work indicator with weekly hours of workers, and working time decreases while implementing the 35-hour work week (Graph 2; Table 3). Thus, WTR firms make use of shift-work to fully compensate for the reduction in the hours of work of their employees.

\footnotetext{
${ }^{28}$ Table A3 in Appendix presents estimated coefficients for the 4 full specifications of linear DID (one for each COT indicator). Estimations were run computing robust or clustered standard errors.

${ }^{29}$ A propensity score was estimated using two logistic regressions (one for weekly, one for annual COT indicators). Table A4 in appendix provides robust estimated coefficients for the full specification.

${ }^{30} \mathrm{We}$ compute bootstrapped standard errors and confidence intervals (at 5\%) by replicating 200 samples with replacement, following a Uniform statistical law, $(i)$ considering all temporal sequences of the observations, (ii) re-estimating the logistic model, (iii) choosing the 3 bandwidth parameters through the leave-one-out cross validation minimisation criterion (Frölich, 2005), (iv) selecting the bi-weight kernel function, and (v) restricting to common support for each simulation. Finally, to deal with choice-based sampling, we performed matching on the log-odd ratio to get a robust estimate (Heckman and Todd, 2009). To check for common support, we drew the kernel density estimates of estimated propensity score values in the 4 groups of companies. Graph A1 in the Appendix shows that there is sufficient overlap among the 4 curves to proceed to propensity score matching. To ensure that firms are comparable along the whole support of the propensity scores, we estimate the density of the propensity score for each firm that is observed at time $t \in[2001 ; 2002]$ and implemented a WTR between $t=1998$ and $t=2000$ in the other 3 groups of firms. We exclude from the final sample the $2 \%$ of firms $i$ that are characterised by the smallest density values in the other 3 sub-samples (Todd, 2008).

31 As mentioned in 4.3, the numbers of days when the capital equipment is idle (measured over the "before period") were only considered as covariates in the specification of the weekly COT. However, in this case, our results are robust to excluding these variables from the lists of the control variables.
} 
Table 4a. Evaluating the impact of the Aubry reform on Capital Operating Time.

\begin{tabular}{|c|c|c|c|}
\hline Compared time periods & \multicolumn{3}{|c|}{ 2001-2002 vs. $1992-1996$} \\
\hline Variable of interest / Estimator & $\mathrm{OLS}^{\mathrm{a}}$ & PS Matching $^{b}$ & LOR Matching $^{c}$ \\
\hline $\begin{array}{l}\text { WEEKLY Capital Operating } \\
\text { Time: }\end{array}$ & & & \\
\hline - Harmonic mean & $\begin{array}{l}0.60 \\
(1.50)\end{array}$ & $\begin{array}{c}-0.16 \\
(2.49) \\
{[-3.72 ; 6.51]}\end{array}$ & $\begin{array}{c}-0.65 \\
(2.37) \\
{[-2.92 ; 6.17]}\end{array}$ \\
\hline - Arithmetic mean & $\begin{array}{l}3.09 \\
(2.04)\end{array}$ & $\begin{array}{c}1.17 \\
(3.72) \\
{[-7.04 ; 8.57]}\end{array}$ & $\begin{array}{c}0.21 \\
(3.50) \\
{[-5.18 ; 8.53]}\end{array}$ \\
\hline Compared time periods & \multicolumn{3}{|c|}{2001 vs. $1992-1996$} \\
\hline Variable of interest / Estimator & $\mathrm{OLS}^{\mathrm{a}}$ & PS Matching $^{b}$ & LOR Matching $^{c}$ \\
\hline $\begin{array}{l}\text { ANNUAL Capital Operating } \\
\text { Time: }\end{array}$ & & & \\
\hline - Harmonic mean & $\begin{array}{l}2.78 \\
(2.56)\end{array}$ & $\begin{array}{c}0.98 \\
(4.57) \\
{[-10.32 ; 8.40]}\end{array}$ & $\begin{array}{c}0.11 \\
(4.57) \\
{[-8.91 ; 10.60]}\end{array}$ \\
\hline - Arithmetic mean & $\begin{array}{l}5.68 * \\
(3.33)\end{array}$ & $\begin{array}{c}3.31 \\
(5.83) \\
{[-8.86 ; 15.26]}\end{array}$ & $\begin{array}{c}2.02 \\
(5.75) \\
{[-9.69 ; 13.02]}\end{array}$ \\
\hline
\end{tabular}

Source: French COT survey (Banque de France, 1992-2002), administrative files of WTR agreements (DARES, French Ministry of Labour, 2003) and computations based on Tables 5-6.

Field: 3,376 manufacturing firms, excluding the energy sector, with 20 employees or more that signed (1,676 firms) or not a Working Time Reduction agreement between June 1998 and December 2000.

Note: ${ }^{a}$ Linear conditional DID estimating equation (5); ${ }^{b, c}$ Kernel matching on the propensity score (respectively on the log-odd ratio) estimating equation (6). Figures are expressed in percentage. ***, ** and * stand for significance, respectively at a 1\%, 5\% or 10\% level. Standard errors stand within parentheses. For semi-parametric estimators, bootstrapped confidence intervals stand within brackets. Reading: between 1992-1996 and 2001-2002, implementing a working time regulation through the Aubry reform implies a variation of 5.68\% in the annual COT, considering an arithmetic mean for the shift-work indicator and the linear estimator provided by equation (5); this estimate is significant at a $10 \%$ level.

These results confirm those of Leclair (2002) that show the French 35-hour work week didn't affect the capacity utilisation rates on the medium run. There are also in line with Bunel (2001), who shows that firms expand modulation of hours through the implementation of a WTR.

Third, this increase in shift-work may be due either to an increase in the proportion of firms that use shiftwork or to an increase in the shift-work intensity. Estimating equations (5) using a logistic regression ${ }^{32}$ to

\footnotetext{
${ }^{32}$ Blundell and Costa-Dias (2009) show that the identification condition is quite the same in this model as that used for a continuous explained variable. Robust estimates and marginal effects were obtained running our estimations using Stata.
} 
model the fact a company makes use of any kind of shift-work system, we show that the Aubry reform hardly increases the frequency of use in the shift-work systems (Table 4b).

Table 4b. Evaluating the impact of the French 35-hour work week on the propensity of firms to adopt a new shift-work system.

\begin{tabular}{|c|c|c|c|}
\hline Compared time periods & \multicolumn{3}{|c|}{$2001-2002$ vs. $1992-1996$} \\
\hline Variable of interest / Estimator & Logistic $^{a}$ & PS Matching $^{b}$ & LOR Matching $^{c}$ \\
\hline Implementing: & & & \\
\hline Any kind of shift-work system & $\begin{array}{l}-0.22 \\
(3.07)\end{array}$ & $\begin{array}{c}-0.61 \\
(5.16) \\
{[-10.32 ; 9.39]}\end{array}$ & $\begin{array}{c}-1.67 \\
(4.54) \\
{[-8.13 ; 10.02]}\end{array}$ \\
\hline $\begin{array}{l}\text { A discontinuous SW system (two-shift } \\
\text { organisation) }\end{array}$ & $\begin{array}{l}-2.30 \\
(3.44)\end{array}$ & $\begin{array}{c}-1.50 \\
(4.90) \\
{[-11.14 ; 8.30]}\end{array}$ & $\begin{array}{c}-2.42 \\
(4.81) \\
{[-9.75 ; 9.23]}\end{array}$ \\
\hline $\begin{array}{l}\text { A semi-continuous SW system (three-shift } \\
\text { organisation) }\end{array}$ & $\begin{array}{l}4.60 \\
(3.30)\end{array}$ & $\begin{array}{c}8.19^{*} \\
(5.02) \\
{[-3.54 ; 15.30]}\end{array}$ & $\begin{array}{c}8.50^{*} \\
(5.10) \\
{[-3.04 ; 16.62]}\end{array}$ \\
\hline $\begin{array}{l}\text { A continuous SW system (five-shift } \\
\text { organisation) }\end{array}$ & $\begin{array}{l}5.76^{* * *} \\
(2.25)\end{array}$ & $\begin{array}{c}3.38 \\
(4.00) \\
{[-6.69 ; 9.78]}\end{array}$ & $\begin{array}{c}3.26 \\
(4.12) \\
{[-5.02 ; 10.27]}\end{array}$ \\
\hline
\end{tabular}

Source: French COT survey (Banque de France, 1992-2002), administrative files of WTR agreements (DARES, French Ministry of Labour, 2003) and computations based on Tables 5-6.

Field: 3,376 manufacturing firms, excluding the energy sector, with 20 employees or more that signed (1,676 firms) or not a Working Time Reduction agreement between June 1998 and December 2000.

Note: ${ }^{a}$ Non linear conditional DID estimating equation (5) using a logistic regression; ${ }^{b, c}$ Kernel matching on the propensity score (respectively on the log-odd ratio) estimating equation (6). Figures are expressed in percentage. ***,** and * stand for significance, respectively at a 1\%, $5 \%$ or $10 \%$ level. Robust standard errors stand within parentheses. For semi-parametric estimators, bootstrapped confidence intervals stand within brackets.

Reading: between 1992-1996 and 2001-2002, implementing a working time regulation through the Aubry reform implies an increase by $5.76 \%$ in the probability for a firm to implement a continuous shift-work system, considering the logistic version of the estimator provided by equation (5); this estimate is significant at a $1 \%$ level.

Fourth, in sub-section 2.3, we saw that our sample contains both shift-work and non shift-work firms. It is important because the decision of firms to use shift-work is endogenous. Thus, excluding them from our sample would have introduced another source of selection bias. 
Table 4c. Growth rates of Capital Operating Time between before and after the adoption of the Aubry reform: differences between companies that implement a WTR and other companies.

Only firms that make use of shift-work are considered.

\begin{tabular}{|c|c|}
\hline Variable / Comparison & 2001-2002 vs. $1992-1996$ \\
\hline $\begin{array}{l}\text { WEEKLY Capital Operating Time: } \\
\text { - Harmonic mean } \\
\text { - Arithmetic mean }\end{array}$ & $\begin{array}{l}+2.70(2.64) \\
+5.95^{*}(3.28)\end{array}$ \\
\hline Supplied weekly hours of work: & $-4.29^{* * *}(0.05)$ \\
\hline $\begin{array}{l}\text { Shift-work: } \\
\quad \text { - Harmonic mean } \\
\text { - Arithmetic mean }\end{array}$ & $\begin{array}{l}+6.99^{* * *}(2.62) \\
+10.24^{* * *}(3.27)\end{array}$ \\
\hline Variable / Comparison & 2001 vs. $1992-1996$ \\
\hline $\begin{array}{l}\text { ANNUAL Capital Operating Time: } \\
\text { - Harmonic mean } \\
\text { - Arithmetic mean }\end{array}$ & $\begin{array}{l}+3.56(3.58) \\
+6.78(5.60)\end{array}$ \\
\hline $\begin{array}{l}\text { Number of weeks capital equipment } \\
\text { work over a whole year }\end{array}$ & $+2.59(2.05)$ \\
\hline $\begin{array}{l}\text { WEEKLY Capital Operating Time: } \\
\text { - Harmonic mean } \\
\text { - Arithmetic mean }\end{array}$ & $\begin{array}{r}0.98(3.52) \\
+4.19(4.33)\end{array}$ \\
\hline $\begin{array}{l}\text { Supplied weekly hours of work: } \\
\text { Shift-work: } \\
\text { - Harmonic mean } \\
\text { - Arithmetic mean }\end{array}$ & $\begin{array}{l}+5.58^{*}(3.49) \\
+8.80^{* *}(4.33)\end{array}$ \\
\hline
\end{tabular}

Source: French COT survey (Banque de France, 1992-2002) and administrative files of WTR agreements (DARES, French Ministry of Labour, 2003).

Field: 2,218 manufacturing firms, excluding the energy sector, with 20 employees or more that signed (1,190 firms) or not a Working Time Reduction agreement between June 1998 and December 2000.

Note: figures are expressed in percentage. Results provided by running equation (5), without controlling for any covariates (unconditional DID estimates). ***, $* *$ and $*$ stand for significance levels respectively at $1 \%$, 5\% or $10 \%$. Standard errors stand within parentheses.

Reading: between 1992-1996 and 2001-2002, weekly hours of work decreased by $4.29 \%$ in shift-work firms that implement a WTR in comparison to other firms.

However, by construction, non shift-work firms saw their COT mechanically diminish as hours of work fall. Thus, focusing only on shift-work firms, Table 4c shows that when implementing the Aubry reform there was a larger increase in the shift-work intensity than that reported in Table 3. Moreover, WTR shift- 
work firms experienced a larger fall in hours of work. Hence, reducing hours of work did not reduce COT because firms compensate the fall in the hours of work by increasing the shift-work use. Moreover, the Aubry reform did not entail any variation in the frequency of use of any shift-work system.

Table 4d. Evolution in the composition of teams, between before and after the adoption of the Aubry reform: differences between companies that implement a WTR and other companies.

Only firms that make use of shift-work are considered.

\begin{tabular}{l|c}
\hline Shift-work system & $\begin{array}{c}\text { Evolution in the share of the } \\
\text { workforce }\end{array}$ \\
\hline Any kind of shift-work system & $+7.04^{* *}(2.82)$ \\
A discontinuous SW system (two-shift organisation) & $+0.50(2.33)$ \\
A semi-continuous SW system (three-shift organisation) & $+4.14^{* *}(2.15)$ \\
A continuous SW system (five-shift organisation) & $+2.41^{*}(1.30)$ \\
\hline \hline
\end{tabular}

Source: French COT survey (Banque de France, 1992-2002) and administrative files of WTR agreements (DARES, French Ministry of Labour, 2003).

Field: 2,218 manufacturing firms, excluding the energy sector, with 20 employees or more that signed (1,190 firms) or not a Working Time Reduction agreement between June 1998 and December 2000.

Note: figures are expressed in percentage points. Results provided by running the regression (1).***,** and * stand for significance levels respectively at 1\%, 5\% or 10\%. Standard errors stand within parentheses.

Reading: between 1992-1996 and 2001-2002, among shift-work firms, the proportion of the workforce operating in any kind of shift-work system increases by 7.04 percentage points in WTR firms in comparison to what happens in other firms.

Consequently, since COT fully decreases in non shift-work firms by an amount that is equal to the fall in the hours of work, the Aubry reform let the COT unchanged in firms that implement a decrease in the hours of work because shift-work firms not only compensate the fall in the hours of work of their employees, but also the decrease in the COT of non shift-work firms.

Fifth, since we see that the shift-work intensity has increased as a consequence of adopting the Aubry reform, it is important to show how the composition of these teams changed at this moment. Table $4 \mathrm{~d}$ shows the variation in the proportion of workers that are concerned with any of the considered shift-work systems. Indeed, we have to recall that COT indicators we built are based on shift-work indicators that are computed to be means of the number of teams that follow each other within a given shift-work system, weighted by the proportion of the workforce operating each piece of equipment. Table $4 \mathrm{~d}$ show that the 
increase in shift-work intensity in WTR firms (relatively to other firms) is mainly due to an increase in the semi-continuous system $(+4.14$ percentage points in the proportion of the workforce considered with it), and to a lesser extent to an increase in the continuous shift-work system. Since the semi-continuous system refers to a three shifts system where workers operate the same equipment, continuously on weekdays (the firm is closed on Saturdays and Sundays), adopting the Aubry reform has induced an increase in night-shift work and to a lesser extent in the work over the end of the week.

\section{Robustness check/Sensitivity analysis}

In previous sub-section, we consider the period of the regulation is 1997-2000. First, our previous results rely only on firms that implement a working time regulation between 13 June 1998 and December 2000 (85 percent of WTR firms). However, as mentioned in sub-section 3.2, 12 percent of WTR firms signed an agreement in 2001. To take account for them, we can extend the period of the shock to 2001. Second, in sub-section 4.1, we said that initial discussions related to the adoption of the laws were held in 1997 (Askenazy, 2008; Les rapports du Sénat, 1997). Nevertheless, the main discussions were held during the national conference on employment, wages, and work time that took place in October 1997. Moreover, the COT survey is led over the second week of September. Hence, we can also consider the period of the regulation began in 1998. Considering this two alternatives for the period of the shock (1997-2001 and / or 1998-2000), we find that our results hold. The Aubry reform let COT unchanged in WTR firms; thus, they resort to shift-work as a compensating device.

\section{Conclusion}

The goal of this article was to evaluate the impact of the 35-hour working week on COT in France. We merged data from the COT survey and administrative files of the WTR agreement. Using DID estimates to control for selection bias, we found that reducing working time leaves COT unchanged. This means 
that companies make use of shift-work to reorganise and to compensate for the whole of the reduction in the hours of work.

\section{References}

Abadie, A. (2005), Semi-parametric differences-in-differences estimators. Review of Economic Studies, 72 (1), pp. 1-19.

Afsa, C. and Biscourp P. (2004), L'évolution des rythmes de travail entre 1995 et 2001: quel impact des 35 heures?, Economie et Statistique, 376-377, pp. 173-213.

Angrist, J. (2010), Empirical Strategies. University of Roma “Tor Vergata”, lecture.

Anxo, D., Bosch G., Bosworth D., Cette G., Sterner T. and Taddéi D. (1995). Work Patterns and Capital utilization: An International Comparative Study, Kluwer Academic Publishers BV.

Askenazy, P. (2000), Réduction du temps de travail: organisation et conditions de travail. Revue Economique, 51(3), pp. 547-556, 2000.

Askenazy, P. (2001), Réduction du temps de travail et innovations organisationnelles négociées. Revue d'Economie Politique, 111 (1), pp. 247-268.

Askenazy, P. (2003), La dynamique de l'organisation du travail lors de la réduction du temps de travail. Economie et Prévision, 158, pp. 27-46.

Askenazy, P. (2008), A Primer on the 35-Hour in France, 1997-2007. Institute for the Study of Labour, Discussion Paper, No. 3402, 2008.

d'Autume, A. and Cahuc P. (1997), Réduction de la durée du travail, de la contrainte légale à la négociation. Revue Economique, 48 (3), pp. 549-558.

Betancourt, R. R. and Clague C. K. (1981), Capital Utilization, A Theoretical and Empirical Analysis. Cambridge University Press.

Blundell, R. and Costa Dias M. (2009), Alternative approaches to evaluation in empirical microeconomics. Journal of Human Ressources, 44(3), pp. 565-640.

Bosworth, D. and Cette G. (1995), La mesure de la durée d'utilisation des équipements. In Anxo et al. (1995), pp. 101-131.

Bosworth, D., Dawkins P. and Westaway A. (1981), Explaining the Incidence of Shiftworking in Great Britain. Economic Journal, 91(361), pp. 145-157.

Bosworth, D. and Heathfield D. (1995), Organisation du travail et durée d'utilisation des équipements : fondements micro-économiques. In Anxo et al. (1995), pp. 37-75.

Bresnahan, T. F. and Ramey V. A. (1994), Output fluctuations at the plant level. Quarterly Journal of Economics, 109(3), pp. 593-624.

Bunel, M. (2001), The working time reduction impacts on firm reorganization, University of Lyon, GATE working paper, No. 01-19.

Bunel, M. (2004), Aides incitatives et déterminants des embauches des établissements passés à 35 heures. Économie et Statistique, 376-377, pp. 91-115.

Bunel, M. and Jugnot S. (2003), 35 heures. Evaluations de l'effet emploi. Revue Economique, 54(3), pp. 565-574.

Cahuc, P. (2001), L'expérience française de réduction du temps de travail: moins d'emplois, plus d'inégalités. Revue française d'économie, 15(3), pp. 141-166.

Calmfors, L. and Hoel M. (1989), Work sharing and shiftwork. Oxford Economic Papers, New Series, 41(4), pp. 758-773.

Cette, G., Durand B. and Tyl T. (1986), "Réorganiser le travail: une solution pour l'emploi?", Economie et Statistique, 184, pp. 3-23. 
Crépon, B., Leclair M. and Roux S. (2004), RTT, productivité et emploi: nouvelles estimations sur données d'entreprises. Economie et Statistique, 376-377, pp. 153-171.

Doisneau, L. and Daniel C. (1998), Suivi statistique des conventions de réduction collective de la durée du travail. Guide du fichier informatique. DARES, French Ministry of Labour.

Estevão, M., and Sá F. (2008), Are the French Happy with the 35-Hour Workweek? Economic Policy, 23(55), pp. 417-446.

Fiole, M., Passeron V. and Roger M. (2000), Premières évaluations quantitatives des réductions collectives du temps de travail. Document d'études de la DARES, No. 35.

Foss, M. F. Shiftwork, Capital Hours and Productivity Change. Kluwer Academic, 1997.

Fournier, B., Barrat O. and Daniel C. (2001), Réduction du temps de travail: la négociation d'entreprise au premier semestre 2000.Premières Informations, No. 17.2.

Frölich, M. (2005), Matching Estimators and Optimal Bandwidth Choice. Statistics and Computing, 15(3), pp. 197-215.

Gilles, F. (2006), Quels effets des réorganisations sur la date de passage des entreprises aux 35 heures?

Une étude sur données individuelles d'entreprises. Revue Economique, 57(6), pp. 1401-1425.

Gilles, F. and L'Horty Y. (2003), 35 heures et inégalités, Revue Economique, 54(3), pp. 583-594.

Hall, G. (2000), Non-convex costs and capital utilization: a study of production scheduling at automobile assembly plants. Journal of Monetary Economics, 45, pp. 681-716.

Hart, R. A. (1987), Working time and employment. Winchester, Massachusetts: Allen and Unwin, 1987.

Heckman J. J. (1976), The common structure of statistical models of truncation, sample selection, and limited dependent variables and a simple estimator for such models. Annals of Economics and Social Measurement, 5(4), pp. 475-492.

Heckman, J. J., Ichimura H. and Todd P. E. (1998), Matching as an econometric estimator: evidence from evaluating a job training program. Review of Economic Studies, 64, pp. 605-654. Heckman, J. J. and Todd P. E. (2009), Adapting propensity score matching and selection models to choice based samples, Econometrics Journal, 12(s1), pp. S230-S234.

Lee, M.-J. and Kang C. (2006), Identification for difference in differences with cross-section and panel data, Economics Letters, Vol. 92, pp. 270-276.

Kostiuk, P. F. (1990), Compensating differential for shift work. Journal of Political Economy, 98(5), pp. 1054-1075.

Lanfranchi, J., Olsson H. and Skalli A. (2002), Compensating wage differentials and shift work preferences. Economics Letters, 74, pp. 393-398.Langot, F. and Pucci M. (1997), Inégalités face au chômage et progrès technique: la réduction de la durée du travail est-elle souhaitable? In Cahuc and Granier (eds), La réduction du temps de travail. Une solution pour l'emploi? Economica.

Leclair, M. (2002), Réduction du temps de travail et tensions sur les facteurs de production, Economie et Statistique, 359-360, pp. 123-147.

Logeay, C. and Schreiber S. (2006), Testing the effectiveness of the French work-sharing reform: a forecasting approach. Applied Economics, 38(17), pp. 2053-2068.

Marimon, R. and Zilibotti F. (2000), Employment and distributional effects of restricting working time. European Economic Review, 44(7), pp. 1291-1326.

Mayshar, J. and Halevy Y. (1997), Shiftwork. Journal of Labor Economics, 15(1), Part 2: Essays in Honor of Yoram Ben-Porath, pp. S198-S222.

Mayshar, J. and Solon G. (1993), Shiftwork and the Business Cycle. American Economic Review, 83(2), pp. 224-228.

McNabb, R. (1989), Compensating wage differentials: some evidence for Britain. Oxford Economic Papers, 41(2), pp. 327-338.

Oi, W.Y. (1981), Slack capacity: productive or wasteful? American Economic Review, 71(2), pp. 64-69.

Ortega, J. (2003), Working-time regulation, firm heterogeneity, and efficiency. CEPR working paper, No. 3736.

Osuna, V. and Rios-Rull V. (2003), Implementing the 35 Hour Workweek by Means of Overtime Taxation. Review of Economic Dynamics, 6(1), pp. 179-206.

Les Rapports du Sénat (1997), Réduction autoritaire du temps de travail à 35 heures. On ne spécule pas avec l'espoir des français. 
De Regt, E. R. (2002), Shifwork, operating time and working time. In de Regt Erik R., Employment, Wages and Working Time, Ph. D Thesis, Chapt. 4

Rocheteau, G. (2002), Working time regulation in a search economy with worker moral hazard. Journal of Public Economics, 84(3), pp. 387-425.

Rosenbaum, P. and Rubin D. (1983), The central role of the propensity score in observational studies for causal effects. Biometrika, 70(1), pp. 41-55.

Rubin, D. (1974), Estimating causal effects of treatments in randomized and non randomized studies. Journal of Educational Psychology, 66, pp. 688-701.

Shapiro, M. D. (1993), Cyclical productivity and the workweek of capital. American Economic Review, 83(2), pp. 229-233.

Sylvain, A. (2001), La durée d'utilisation des équipements : principaux résultats 1989-2000. Observatoire des Entreprises, Banque de France, Bulletin de la Banque de France, No. 94.

Sylvain, A. (2004), Pertinence empirique des mesures indirectes de la durée d'utilisation des équipements. Banque de France, manuscript. In A. Sylvain, Le partage de la valeur ajoutée en France depuis 1970, Ph. D Thesis, 2004.

Todd, P. E. (2008), Matching Estimators. In S. N. Durlauf and L. E. Blume (eds), The New Palgrave Dictionary of Economics, Second Edition, Palgrave Macmillan.

Wooldridge, J. M. (2003), Introductory Econometrics: A Modern Approach. Second edition. Cincinnati, $\mathrm{OH}$ : South-Western College Publishing.

Wooldridge, J. M. (2010), Econometric analysis of cross section and panel data. Second Edition. Cambridge, MA: MIT Press. 


\section{Appendix}

Graph A1. Propensity score estimated densities following the outcome variable is the weekly capital operating time or the annual capital operating time.

4.a. For WEEKLY capital operating time:

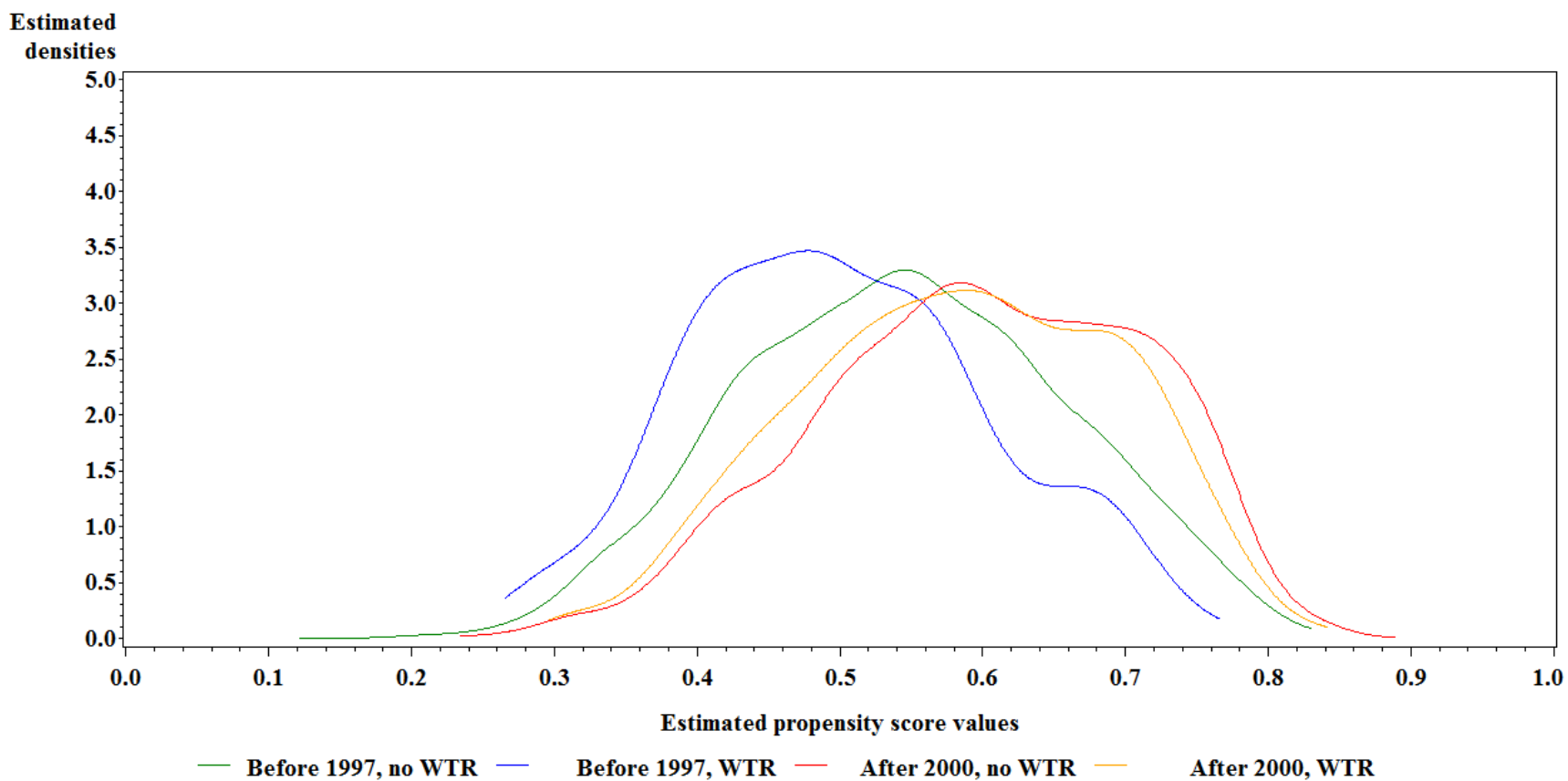

4.b. For ANNUAL capital operating time:

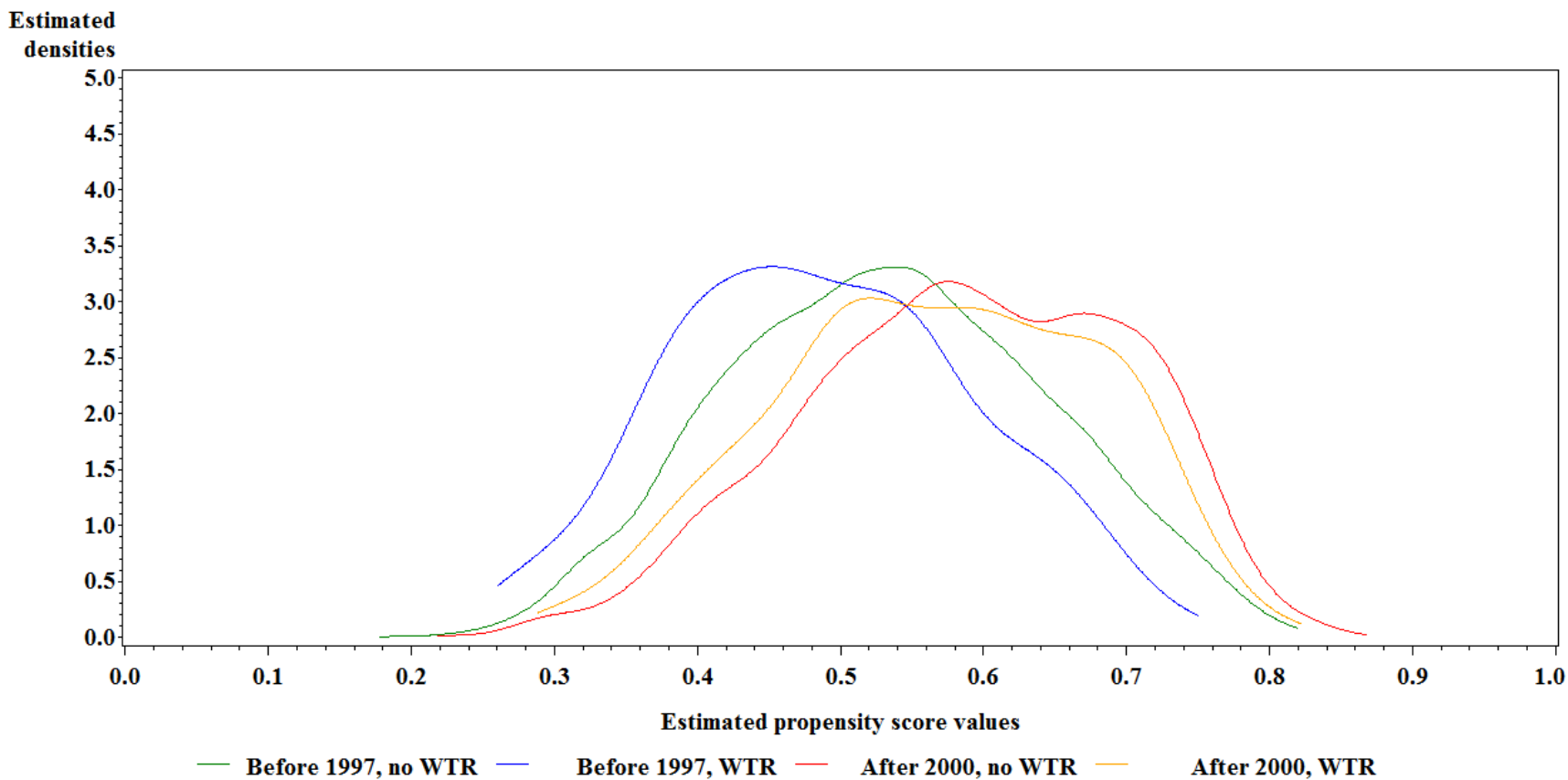

Source: French COT survey (Banque de France, 1992-2002) and administrative files of WTR agreements (DARES, French Ministry of Labour, 2003).

Field: 3,376 manufacturing firms, excluding the energy sector, with 20 employees or more that signed (1,676 firms) or not a Working Time Reduction agreement between June 1998 and December 2000. 
As variables to build COT indicators

Supplied hours of work

Discontinuous shift-workers

Semi-continuous shift-workers

Continuous shift-workers

\section{As control variables}

Business sector of activity:

Agricultural and food industries,

Clothing and leather

Edition, printing works and reproduction

Pharmacy, perfumery and cleaning service

Car industry

Home equipment

Shipbuilding, aircraft and train construction

Mechanical equipment

Electric and electronic equipment

Mineral products

Textile industry

Wood and paper industry

Chemistry, rubber and plastic industry

Metallurgical industry

Electric and electronic components

Number of workers employed by the firm:

Fewer than 28 workers

Between 29 and 49 workers

Between 50 and 99 workers

Between 100 and 249 workers

Between 250 and 499 workers

More than 500 workers

Numbers of days capital equipment do not work:

Over the week

Over the year, paid holiday

Over the year, seasonal activity

Over the year, public holiday

Over the year, other motives

First obstacle to a future increase in the COT is: The reluctance of employed people

The union position

A lack of skilled workers

A bottleneck on raw materials or stocks

A technical obstacle

Due to labour law or regulations

The company is forced to sign a branch agreement

The company is forced to sign a firm agreement

Other obstacle

No obstacle

Capacity utilisation rate:

Without new hires

With new hires

Ways considered to change past weekly COT: Increase / decrease in hours of work

Increase / decrease in shift-work

New capital equipment

Other source
Definitions

Number of weekly hours of work at company level (arithmetic mean of individual employees' hours of work). It include breaks (for food, changes of clothing), as well as normal overtime working decided on through collective agreements. It does not include short-time working or absenteeism.

Number of workers that operate a given capital equipment within a two-shift work schedule.

Number of workers that operate a given capital equipment within a three-shift work schedule.

Number of workers that operate a given capital equipment within a five-shift work schedule.

Set of business sector dummies, that are equal to 1 if the firm operates in the given business sector, or to 0 else. We consider 16 business sectors according to the NES16 grouping of the French standard industrial classification (Nomenclature d'activités françaises, NAF).

"Electric and electronic components" is the reference variable in our estimations.

Set of 6 dummies for firm size, that are equal to 1 if the firm employs a given number of workers, or to 0 else. Firm size is measured through full-time equivalent workforce. It includes all of the firm's permanent and temporary employees.

"Between 29 and 49 workers" is the reference variable in our estimations' tables.

Weekly or annual number of days when the capital equipment is idle for different reasons. The reasons for capital equipment being idle include mainly paid holidays, seasonal activity and public holidays or other motives (e.g. short-time working, strike, technical problems or bad weather).

Set of 9 dummies that are equal to 1 if the given obstacle is the most important met by the firm if it wants to increase COT in the future, and 0 else. Indeed, the COT survey asks companies whether there are likely to be some obstacles to increasing COT. Firms were supposed to rank these obstacles, from the most to the less important. We then built these 9 dummies that refer to the most important obstacle.

"No obstacle" is the reference variable in our estimations' tables.

Capacity utilisation rates in percentage. They are available for both cases with or without new hires. There were computed as the ratio of 1 to 1 plus the 'production margins'. Production margins (or 'capacity margins') are provided by the COT survey where firms were asked to what extent they can increase production using already installed equipment, with or without increasing their workforce.

Set of 6 dummies providing information on how the company has changed average weekly COT in the past: increasing or decreasing intensity of shift-working; increasing or decreasing weekly hours of work; investing in new capital equipment; other ways (e.g. short-time working).

These modalities are not mutually exclusive. 
Table A2. Descriptive statistics dealing with control variables.

Following the firm makes use of shift-work or not.

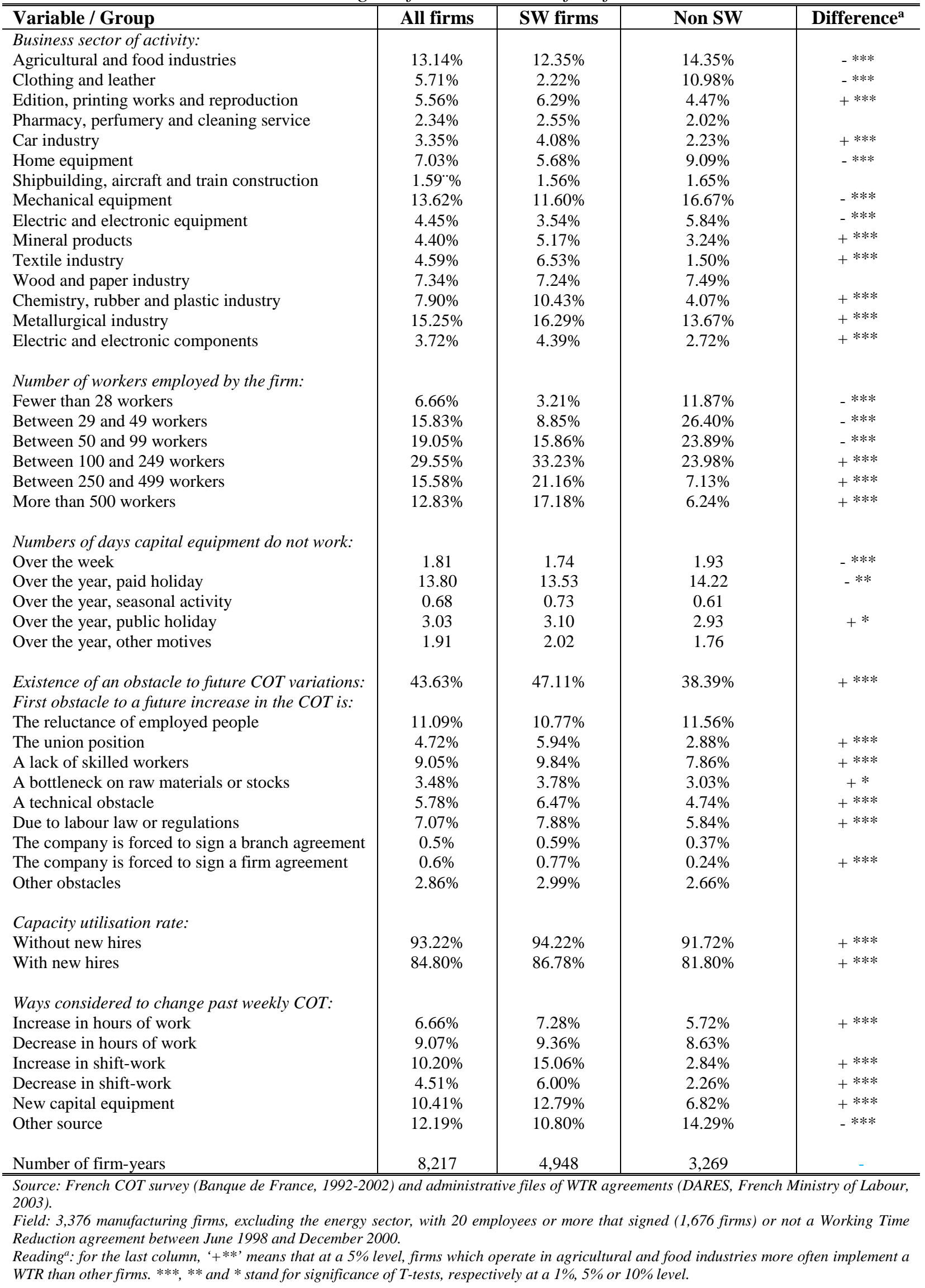


Table A3. Evaluating the impact of the French 35-hour work week on Capital Operating Time, using a linear DID. Full specifications.

\begin{tabular}{|c|c|c|c|c|}
\hline Variable / COT variable & $\begin{array}{c}\text { Weekly COT } \\
\text { Harmonic Mean }\end{array}$ & $\begin{array}{c}\text { Weekly COT } \\
\text { Arithmetic mean }\end{array}$ & $\begin{array}{c}\text { Annual COT } \\
\text { Harmonic mean }\end{array}$ & $\begin{array}{c}\text { Annual COT } \\
\text { Arithmetic mean }\end{array}$ \\
\hline $\begin{array}{l}\text { Intercept } \\
\text { Dummy for } 1993 \\
\text { Dummy for } 1994 \\
\text { Dummy for } 1995 \\
\text { Dummy for } 1996\end{array}$ & $\begin{array}{c}3.4935 * * *(0.0386) \\
-0.0108(0.0077) \\
-0.0175 * *(0.0079) \\
0.0020(0.0080) \\
-0.0053(0.0082) \\
\end{array}$ & $\begin{array}{c}3.5283 * * *(0.0482) \\
-0.0197 * *(0.0096) \\
-0.0359 * * *(0.0098) \\
0.0014(0.0099) \\
-0.0104(0.0102)\end{array}$ & $\begin{array}{c}7.0827 * * *(0.0484) \\
-0.0240 * *(0.0097) \\
-0.0411 * * *(0.0099) \\
-0.0041(0.0099) \\
-0.0188 *(0.0102) \\
\end{array}$ & $\begin{array}{c}7.1250 * * *(0.0593) \\
-0.0310 * * *(0.0119) \\
-0.0565 * * *(0.0121) \\
-0.0030(0.0122) \\
-0.0221 *(0.0125) \\
\end{array}$ \\
\hline $\begin{array}{l}\text { Dummy:firm observed after August } 2001 \\
\text { Dummy: WTR between Jun. } 1998 \text { and Dec. } 2000 \\
\text { Firm observed after } 2000 \\
x \text { WTR between Jun. } 1998 \text { and Dec. } 2000\end{array}$ & $\begin{array}{c}-0.0763 * * *(0.0146) \\
-0.0146 * * *(0.0055) \\
0.0060(\boldsymbol{0 . 0 1 7 0})\end{array}$ & $\begin{array}{c}-0.0723 * * *(0.0182) \\
-0.0124 *(0.0068) \\
\mathbf{0 . 0 3 0 9}(\boldsymbol{0 . 0 2 1 3})\end{array}$ & $\begin{array}{c}-0.09190^{* * *}(0.0234) \\
-0.0116^{*}(0.0067) \\
0.0278(\boldsymbol{0 . 0 2 7 2})\end{array}$ & $\begin{array}{c}-0.0916^{* * *}(0.0286) \\
-0.0091(0.0083) \\
0.0568 *(0.0334)\end{array}$ \\
\hline $\begin{array}{l}\text { Business sector of activity: } \\
\text { Agricultural and food industries } \\
\text { Clothing and leather } \\
\text { Edition, printing works and reproduction } \\
\text { Pharmacy, perfumery and cleaning service } \\
\text { Car industry } \\
\text { Home equipment } \\
\text { Shipbuilding, aircraft and train construction } \\
\text { Mechanical equipment } \\
\text { Electric and electronic equipment } \\
\text { Mineral products } \\
\text { Textile industry } \\
\text { Wood and paper industry } \\
\text { Chemistry, rubber and plastic industry } \\
\text { Metallurgical industry } \\
\text { Electric and electronic components }\end{array}$ & $\begin{array}{c}0.0455 * * *(0.0150) \\
-0.1143 * * *(0.0170) \\
0.0907 * * *(0.0172) \\
-0.1118 * * *(0.0209) \\
0.0578 * * *(0.0189) \\
-0.0462 * * *(0.0162) \\
-0.1057 * * *(0.0236) \\
-0.0514 * * *(0.0148) \\
-0.0860 * * *(0.0176) \\
0.0971 * * *(0.0178) \\
0.1622 * * *(0.0177) \\
0.0950 * * *(0.0162) \\
0.1536 * * *(0.0158) \\
0.0593 * * *(0.0146) \\
R E F .\end{array}$ & $\begin{array}{c}0.0347 *(0.0188) \\
-0.1738 * * *(0.0212) \\
0.1012 * * *(0.0215) \\
-0.1280 * * *(0.0261) \\
0.0559 * *(0.0237) \\
-0.0752 * * *(0.0203) \\
-0.1398 * * *(0.0295) \\
-0.0782 * * *(0.0185) \\
-0.1253 * * *(0.0220) \\
0.1227 * * *(0.0222) \\
0.2194 * * *(0.0221) \\
0.1231 * * *(0.0202) \\
0.2389 * * *(0.0198) \\
0.0827 * * *(0.0183) \\
\text { REF. }\end{array}$ & $\begin{array}{c}0.0618 * * *(0.0187) \\
-0.1799 * * *(0.0211) \\
0.1064 * * *(0.0215) \\
-0.1089 * * *(0.0262) \\
0.0270(0.0236) \\
-0.0861 * * *(0.0203) \\
-0.1274 * * *(0.0296) \\
-0.0638 * * *(0.0186) \\
-0.0942 * * *(0.0221) \\
0.1229 * * *(0.0224) \\
0.1551 * * *(0.0221) \\
0.0896 * * *(0.0204) \\
0.1757 * * *(0.0200) \\
0.0637 * * *(0.0184) \\
R E F .\end{array}$ & $\begin{array}{c}0.0529 * *(0.0229) \\
-0.2362 * * *(0.0259) \\
0.1159 * * *(0.0264) \\
-0.1239 * * *(0.0321) \\
0.0280(0.0289) \\
-0.1132 * * *(0.0248) \\
-0.1585 * * *(0.0363) \\
-0.0890 * * *(0.0227) \\
-0.1335 * * *(0.0271) \\
0.1507 * * *(0.0274) \\
0.2133 * * *(0.0270) \\
0.1177 * * *(0.0250) \\
0.2595 * * *(0.0244) \\
0.0889 * * *(0.0225) \\
R E F .\end{array}$ \\
\hline $\begin{array}{l}\text { Number of workers employed by the firm: } \\
\text { Fewer than } 28 \text { workers } \\
\text { Between } 29 \text { and } 49 \text { workers } \\
\text { Between } 50 \text { and } 99 \text { workers } \\
\text { Between } 100 \text { and } 249 \text { workers } \\
\text { Between } 250 \text { and } 499 \text { workers } \\
\text { More than } 500 \text { workers }\end{array}$ & $\begin{array}{c}-0.0215 *(0.0115) \\
R E F . \\
0.0477 * * *(0.0085) \\
0.0967 * * *(0.0079) \\
0.1424 * * *(0.0093) \\
0.1368 * * *(0.0101)\end{array}$ & $\begin{array}{c}-0.0247 *(0.0144) \\
R E F . \\
0.0729 * * *(0.0106) \\
0.1409 * * *(0.0098) \\
0.2047 * * *(0.0116) \\
0.2006 * * *(0.0126)\end{array}$ & $\begin{array}{c}-0.0194(0.0147) \\
R E F . \\
0.0506 * * *(0.0107) \\
0.1157 * * *(0.0100) \\
0.1825 * * *(0.0117) \\
0.1918 * * *(0.0128)\end{array}$ & $\begin{array}{c}-0.0220(0.0180) \\
R E F . \\
0.0754 * * *(0.0131) \\
0.1609 * * *(0.0122) \\
0.2441 * * *(0.0144) \\
0.2529 * * *(0.0157)\end{array}$ \\
\hline $\begin{array}{l}\text { Numbers of days capital equipment do not work: } \\
\text { Over the week } \\
\text { Over the year, paid holiday } \\
\text { Over the year, seasonal activity } \\
\text { Over the year, public holiday } \\
\text { Over the year, other motives }\end{array}$ & $\begin{array}{c}-0.0752 * * *(0.0044) \\
0.0006 * * *(0.0002) \\
0.0012 * *(0.0006) \\
0.0002(0.0006) \\
0.0005(0.0003)\end{array}$ & $\begin{array}{c}-0.1443 * * *(0.0055) \\
0.0006 * *(0.0003) \\
0.0013 *(0.0007) \\
-0.0000(0.0008) \\
0.0013 * * *(0.0004)\end{array}$ & $\begin{aligned}-0.1544 * * *(0.0055) \\
- \\
- \\
- \\
-\end{aligned}$ & $\begin{aligned}-0.2241 * * *(0.0067) \\
- \\
- \\
- \\
-\end{aligned}$ \\
\hline $\begin{array}{l}\text { First obstacle to a future increase in the COT is: } \\
\text { The reluctance of employed people } \\
\text { The union position } \\
\text { A lack of skilled workers } \\
\text { A bottleneck on raw materials or stocks } \\
\text { A technical obstacle } \\
\text { Due to labour law or regulations } \\
\text { The company is forced to sign a branch agreement } \\
\text { The company is forced to sign a firm agreement } \\
\text { Other obstacle } \\
\text { No obstacle }\end{array}$ & $\begin{array}{c}-0.0052(0.0082) \\
0.0271 * *(0.0121) \\
0.0268 * *(0.0090) \\
-0.0025(0.0139) \\
0.0190 *(0.0110) \\
0.0439^{*} * *(0.0099) \\
-0.0681 *(0.0358) \\
0.1053 * * *(0.0337) \\
0.0701 * * *(0.0151) \\
R E F .\end{array}$ & $\begin{array}{l}-0.0068(0.0102) \\
0.0316 * *(0.0152) \\
0.0283 * *(0.0112) \\
-0.0008(0.0173) \\
0.0347 * *(0.0138) \\
0.0431 * * *(0.0124) \\
-0.0900 * *(0.0447) \\
0.1371 * * *(0.0421) \\
0.0869 * * *(0.0189) \\
R E F .\end{array}$ & $\begin{array}{c}-0.0090(0.0103) \\
0.0162(0.0153) \\
0.0148(0.0114) \\
0.0002(0.0176) \\
0.0362 * *(0.0139) \\
0.0337 * * *(0.0126) \\
-0.0855 * *(0.0456) \\
0.1015 * *(0.0428) \\
0.0746 * * *(0.0193) \\
R E F .\end{array}$ & $\begin{array}{c}-0.0109(0.0126) \\
0.0207(0.0187) \\
0.0153(0.0139) \\
0.0017(0.0215) \\
0.0531 * * *(0.0170) \\
0.0329 * *(0.0154) \\
-0.1041 *(0.0558) \\
0.1264 * *(0.0524) \\
0.0890 * * *(0.0236) \\
R E F .\end{array}$ \\
\hline $\begin{array}{l}\text { Capacity utilisation rate: } \\
\text { Without new hires } \\
\text { With new hires }\end{array}$ & $\begin{array}{l}0.1651 * * *(0.0503) \\
0.2510 * * *(0.0373)\end{array}$ & $\begin{array}{c}0.1285 * *(0.0628) \\
0.4610 * * *(0.0466)\end{array}$ & $\begin{array}{c}0.1819 * *(0.0632) \\
0.3943 * * *(0.0470)\end{array}$ & $\begin{array}{c}0.1365 *(0.0774) \\
0.6043 * * *(0.0576)\end{array}$ \\
\hline $\begin{array}{l}\text { Ways considered to change past weekly COT: } \\
\text { Increase in hours of work } \\
\text { Decrease in hours of work } \\
\text { Increase in shift-work } \\
\text { Decrease in shift-work } \\
\text { New capital equipment } \\
\text { Other source }\end{array}$ & $\begin{array}{c}0.0022(0.0102) \\
-0.0180 * *(0.0089) \\
0.0674 * * *(0.0090) \\
0.0635 * * *(0.0124) \\
0.0158 *(0.0086) \\
-0.0011(0.0076)\end{array}$ & $\begin{array}{c}-0.0061(0.0127) \\
-0.0203 *(0.0112) \\
0.0818 * * *(0.0112) \\
0.0799 * * *(0.0155) \\
0.0232 * *(0.0108) \\
-0.0022(0.0095)\end{array}$ & $\begin{array}{c}-0.0148 *(0.0128) \\
-0.0190 *(0.0112) \\
0.0707 * * *(0.0113) \\
0.0564 * * *(0.0156) \\
0.0217(0.0109) \\
-0.0036(0.0096)\end{array}$ & $\begin{array}{c}-0.0222(0.0157) \\
-0.0200(0.0137) \\
0.0830 * * *(0.0139) \\
0.0733 * * *(0.0191) \\
0.0267 *(0.0134) \\
-0.0049(0.0118)\end{array}$ \\
\hline Number of observations (firm-years) & 8217 & 8217 & 7760 & 7760 \\
\hline Adjusted R-Squared & 0.2629 & 0.3476 & 0.3248 & 0.3780 \\
\hline
\end{tabular}

Source: French COT survey (Banque de France, 1992-2002) and administrative files of WTR agreements (DARES, French Ministry of Labour, 2003).

Fild: 376 manufacturing firms, excluding the energy sector, with 20 employees or more that signed (1,676 firms) or not a Working Time Reduction agreement between June 1998 and December 2000.

Note ${ }^{a}$ : estimates are obtained through the estimation of a dichotomous logit model. Robust standard errors stand within parentheses. ***, ** and * stand for significance at, respectively, a $1 \%, 5 \%$ or $10 \%$ level. 
Table A4. Modelling the probability for a firm to adopt a WTR. Following the firm implements or not a WTR between June 1998 and December 2000.

\begin{tabular}{|c|c|c|}
\hline Variable / COT variable & Weekly COT & Annual COT \\
\hline Intercept & $-1.8194 * * *(0.3548)$ & $-1.9357 * * *(0.3614)$ \\
\hline Dummy for 1993 & $0.1352 *(0.0704)$ & $0.1913 * * *(0.0723)$ \\
\hline Dummy for 1994 & $0.0456(0.0716)$ & $0.1300 *(0.0731)$ \\
\hline Dummy for 1995 & $0.1343 *(0.0722)$ & $0.2048 * * *(0.0734)$ \\
\hline Dummy for 1996 & $0.2985 * * *(0.0747)$ & $0.3787 * * *(0.0760)$ \\
\hline \multicolumn{3}{|l|}{ Business sector of activity: } \\
\hline Agricultural and food industries & $0.4074 * * *(0.1395)$ & $0.3555 * *(0.1406)$ \\
\hline Clothing and leather & $0.1375(0.1562)$ & $0.0687(0.1577)$ \\
\hline Edition, printing works and reproduction & $0.4098 * * *(0.1589)$ & $0.4074 * *(0.1613)$ \\
\hline Pharmacy, perfumery and cleaning service & $0.0848(0.1943)$ & $0.0664(0.1976)$ \\
\hline Car industry & $-0.3458 * *(0.1739)$ & $-0.3227 *(0.1759)$ \\
\hline Home equipment & $0.2515 *(0.1499)$ & $0.2260(0.1520)$ \\
\hline Shipbuilding, aircraft and train construction & $0.3587(0.2243)$ & $0.3168(0.2272)$ \\
\hline Mechanical equipment & $0.0720(0.1362)$ & $0.0558(0.1389)$ \\
\hline Electric and electronic equipment & $-0.2419(0.1617)$ & $-0.2258(0.1655)$ \\
\hline Mineral products & $0.5169 * * *(0.1665)$ & $0.5080 * * *(0.1699)$ \\
\hline Textile industry & $0.4028 * *(0.1642)$ & $0.3713 * *(0.1663)$ \\
\hline Wood and paper industry & $0.1189(0.1487)$ & $0.1281(0.1523)$ \\
\hline Chemistry, rubber and plastic industry & $0.3800 * * *(0.1477)$ & $0.3502 * *(0.1506)$ \\
\hline Metallurgical industry & $0.1679(0.1351)$ & $0.1875(0.1380)$ \\
\hline Electric and electronic components & $R E F$ & REF. \\
\hline \multicolumn{3}{|l|}{ Number of workers employed by the firm: } \\
\hline Fewer than 28 workers & $-0.2475 * *(0.1048)$ & $-0.2492 * *(0.1092)$ \\
\hline Between 29 and 49 workers & $R E F$ & $R E F$ \\
\hline Between 50 and 99 workers & $0.2800 * * *(0.0761)$ & $0.2891 * * *(0.0783)$ \\
\hline Between 100 and 249 workers & $0.5003 * * *(0.0709)$ & $0.5039 * * *(0.0731)$ \\
\hline Between 250 and 499 workers & $0.9729 * * *(0.0861)$ & $0.9558 * * *(0.0881)$ \\
\hline More than 500 workers & $1.0390 * * *(0.0951)$ & $1.0315 * * *(0.0973)$ \\
\hline \multicolumn{3}{|l|}{ Numbers of days capital equipment do not work: } \\
\hline Over the week & $-0.0356(0.0412)$ & $-0.0340(0.0415)$ \\
\hline Over the year, paid holiday & $-0.0000(0.0022)$ & - \\
\hline Over the year, seasonal activity & $-0.0165 * * *(0.0057)$ & - \\
\hline Over the year, public holiday & $-0.0059(0.0058)$ & - \\
\hline Over the year, other motives & $0.0008(0.0032)$ & - \\
\hline \multicolumn{3}{|l|}{ First obstacle to a future increase in the COT is: } \\
\hline The reluctance of employed people & $0.1567 * *(0.0764)$ & $0.1551 * *(0.0781)$ \\
\hline The union position & $0.0878(0.1162)$ & $0.0712(0.1181)$ \\
\hline A lack of skilled workers & $0.0353(0.0822)$ & $0.0363(0.0848)$ \\
\hline A bottleneck on raw materials or stocks & $-0.2500 * *(0.1264)$ & $-0.2327 *(0.1300)$ \\
\hline A technical obstacle & $-0.1341(0.1016)$ & $-0.1483(0.1037)$ \\
\hline Due to labour law or regulations & $-0.0510(0.0915)$ & $-0.0778(0.0938)$ \\
\hline The company is forced to sign a branch agreement & $0.5907(0.3635)$ & $0.5361(0.3686)$ \\
\hline The company is forced to sign a firm agreement & $0.1956(0.3302)$ & $0.2351(0.3409)$ \\
\hline Other obstacle & $0.1727(0.1410)$ & $0.1556(0.1454)$ \\
\hline No obstacle & $R E F$ & $R E F$ \\
\hline \multicolumn{3}{|l|}{ Capacity utilisation rate: } \\
\hline Without new hires & $1.1700 * * *(0.4610)$ & $1.1542 * * *(0.4702)$ \\
\hline With new hires & $0.3607(0.3429)$ & $0.3937(0.3506)$ \\
\hline \multicolumn{3}{|l|}{ Ways considered to change past weekly COT: } \\
\hline Increase in hours of work & $-0.0063(0.0945)$ & $-0.0296(0.0961)$ \\
\hline Decrease in hours of work & $-0.0171(0.0827)$ & $0.0007(0.0841)$ \\
\hline Increase in shift-work & $-0.0674(0.0842)$ & $0.0670(0.0859)$ \\
\hline Decrease in shift-work & $0.2926 * *(0.1180)$ & $0.2603 * *(0.1200)$ \\
\hline New capital equipment & $0.0746(0.0805)$ & $0.0771(0.0824)$ \\
\hline Other source & $-0.1010(0.0702)$ & $-0.1048(0.0719)$ \\
\hline Number of observations (firm-years) & 8,217 & 7,760 \\
\hline
\end{tabular}




\section{Documents de travail récents}

- Marc Germain "NIMBY, taxe foncière et vote par les pieds" [2013-36]

- Aurélie Mahieux and Lucia Mejia-Dorantes: "The Impacts of public transport policies on a non mobility area: French study case in the north of France" [2013-35]

- Richard Duhautois and Fabrice Gilles: "Payroll tax reductions and job flows in France" [2013-34]

- Cristina Badarau, Florence Huart and Ibrahima Sangaré : "Indebtedness and macroeconomic imbalances in a monetary-union DSGE" [2013-33]

- Marion Drut: "Vers un système de transport opérant selon les principes de l'économie de la fonctionnalité?" [2013-32]

- Jérôme Héricourt and Sandra Poncet : "Exchange Rate Volatility, Financial Constraints and Trade: Empirical Evidence from Chines" [2013-31]

- Jean-Baptiste Desquilbet et Fédi Kalai : "La banque conventionnelle et la banque islamique avec fonds propres : contrat de dépôt et partage du risque de liquidité" [2013-30]

- Cécily Defoort and Carine Drapier: "Immigration and its dependence on the welfare system: the case of France" [2012-29]

- Carine Drapier and Nadiya Ukrayinchuk : "Les conditions de travail et la santé des immigrés : Seraient- ils plus résistants à la pénibilité au travail que les natifs ?" [2012-28]

- Etienne Farvaque, Muhammad Azmat Hayat and Alexander Mihailov: "Who Supports the ECB?Evidence from Eurobarometer Survey Data" [2012-27]

- Nathalie Chusseau, Joël Hellier and Bassem Ben-Halima: "Education, Intergenerational Mobility and Inequality" [2012-26]

- Nathalie Chusseau and Joël Hellier : "Inequality in Emerging Countries" [201225]

- Nathalie Chusseau and Michel Dumont: "Growing Income Inequalities in Advanced" [2012-24]

- Kirill Borissov and Stéphane Lambrecht : "The dynamics of income inequality in a growthmodel with human capital and occupational choice" [2012-23]

- Thomas Baudin: "More on Religion and Fertility: The French Connection" [2012-22] 